\title{
Multivariate analyses document host specificity, differences in the diatom metaphyton vs. epiphyton, and seasonality that structure the epiphytic diatom community
}

\author{
Linda K. Medlin ${ }^{\mathrm{a}, *}$, Steve Juggins ${ }^{\mathrm{b}}$ \\ ${ }^{a}$ Marine Biological Association of the UK, The Citadel, Plymouth PL1 2PB, UK \\ ${ }^{\mathrm{b}}$ Newcastle University, Newcastle Upon Tyne, NE1 7RU, UK
}

\section{A R T ICLE INFO}

\section{Keywords:}

Epiphytic diatoms

Community composition statistics

Multivariate analyses

\begin{abstract}
A B S T R A C T
Epiphytic diatom community structure associated with selected macroalgae collected from jetties at Galveston, Port Aransas, and Port Isabel, Texas was investigated using multivariate and community statistics. Redundancy analyses revealed community variation attributable to treatment (4\% in Galveston, up to 8-12\% at Port Isabel and Port Aransas), to host plant (6-9\%) and to season (ca 14\%). Shared effects between pairs of factors were between 1 and $2 \%$ or less, indicating factors tested acted independently and significantly to vary the diatom community structure over a two year period. A coastal salinity gradient explained 16\% of the variation. Host specificity was documented and correlated with season. Treatment included a wash, tip and base preparation processed to analyze metaphyton and epiphyton separately and determine zonation on hosts and within the narrow intertidal $(11-25 \mathrm{~cm})$. Wash assemblages were statistically different and more diverse than attached assemblages during the fall/spring but were more alike in winter when hosts were senescent. It is recommended that future studies of epiphytic communities take advantage of rinsing or washing the host plant to capture this important and significant part of the diatom community associated with macroalgae. Variation between hosts was greater than variation among host replicates, in abundance rather than identity.
\end{abstract}

\section{Introduction}

Diatoms comprise one of the mosttimportant microalgal groups, contributing to species richness and primary production in many habitats (Underwood and Kromkamp, 1999). Some habitats, viz., the plankton, have been extensively studied (Round et al., 1990). Benthic habitats, well defined spatially: epipelic (on silt), epipsammic (on sand), epilithic (on rocks), epiphytic (on plants) and epizoic (on animals), are less well known (Round, 1971, 1980; Tiffany, 2011).

Epiphytic diatoms living attached to a host or in the mucilaginous waters surrounding it (metaphyton, Behre, 1943) must interact with biologically active compounds being secreted by the host that may enhance or deter growth. Gough and Gough (1981) who had observed differences in epiphyton composition between morphologically similar macrophytes growing close to each other and concluded that some macrophytes may be neutral hosts to their epiphyton, whereas others may dramatically affect epiphytic growth. Auxin-like (growth enhancing) compounds have been documented from macroalgae (Overbeek,

\footnotetext{
* Corresponding author.

Email address: 1km@mba.ac.uk (L.K. Medlin)
}

1940; Le Bail et al., 2010), but their effects on epiphytic growth are un-investigated. 'Antibiosis', defined as the antagonistic association between one organism and a metabolic produce of another is well documented in land plants because specific compounds can be identified as repellents or attractants for predators (Barbosa et al., 2014; Pramitha and Lipton, 2013; Sieburth and Thomas, 1973). These are secondary metabolites and, where studied, seem to be a controlling factor in biotic interactions (Steinberg and deNys, 2002), especially antibacterial activity (Hornsey and Hide, 1974; 1976a; b; Sanmukh et al., 2014) and allelopathic activity (Medlin and Cembella, 2012).

Host plants can depress the epiphytic community either by secreting secondary compounds, by sloughing epidermal cells or by accelerating its own growth to offset epiphytic growth (Mutinová, 2015; Sand-Jensen, 1977; Sieburth and Tootle, 1981). If the host is nitrogen limited, then its mucilage layer dissolves, retarding epiphyte settlement (Fitzgerald, 1969). Epiphyte growth can be enhanced with the uptake of host-derived nutrients (Harlin 1973; McRoy \& Goering 1974). Epiphytes provide food for grazing invertebrates and have their own unique $\mathrm{C}^{13}$ signal so that their identity can be traced (Moncreiff and Sullivan, 2001). 
Diatoms attached directly to a host respond to chemicals differently. The obvious response is epiphyte absence. If present, then abundance and the means of attachment to the host indicate a tolerance of these chemicals and/or if the host plant is producing antagonistic products (Hendey, 1951; Sieburth, 1968). Tanaka (1986) classified the adhesive strength of diatoms from 10 microalgal hosts and suggested that attachment means was an indication of diatom tolerances to biotic factors from the hosts and abiotic factors. Stalk-attached diatoms uplift cells (Daniel et al., 1980; Evans, 1981) and stalk length varies in response to biotoxins (Callow and Evans, 1981). Amphora and Mastogloia are encapsulated in mucilage (protection from biotoxins). Amphora sequesters copper containing granules within cell vacuoles for protection against toxicity (Daniel et al., 1980). If the plant's meristem, the primary source for antibiosis compound production, is at the apex, then a decrease downward in epiphyte abundance is seen from the tip (Sieburth, 1968; Conover and Sieburth, 1963, Main and McIntyre, 1974; Sieburth and Thomas, 1973; ; Sieburth et al., 1974; Siver, 1980; Medlin et al., 1985).

Antagonistic compounds produced by the host can affect its palatability and, hence, invertebrate grazing (Lubchenco, 1978), altering epiphyte species composition through frequent and/or selective perturbation (Castenholz, 1961; Nicotri, 1977; Medlin, 1981; Underwood and Thomas, 1990). Stalked species are preferentially grazed (Underwood and Thomas, 1990). Sampling of grazing paths of snails on kelps also has shown a decrease of stalked species in the grazed areas as compared to adjacent ungrazed areas (Medlin, 1981). Opportunistic species can quickly colonize the grazed space, or in exclusion experiments the non-grazed control, to add further changes to the community structure (Cattaneo and Kalff, 1986).

Subtle and/or dramatic differences in epiphyte coverage between different hosts has been documented. Differences in epiphyte density or presence/absence, i.e. host specificity, was reported by Godward (1934), Aleem (1950, 1969), Prowse (1959), Hopkins (1964), Eminson and Moss (1980), Holt (1980), Ronnberg and Lax (1980), Rosen et al. (1981), Blindow 1987, Harper and Garbary (1994), Dabek et al. (2015) and Rojas and Hassan (2018). More commonly host specificity has not been reported (Cattaneo and Kalff, 1978; Sullivan, 1977) Most workers have not investigated host specificity or differences in epiphyte density relative to the spatial arrangement of the host plant. Obligate host specificity is only known from endophytic diatoms (Baardseth and Taasen, 1973; Taasen, 1975Lee et al., 1982)굼

Velocity will alter the cell's settling ability (Stevensen, 1981). Any projection from the host will alter fluid mechanics to induce settling (Godward, 1934; Siver, 1980). Most diatom colony structure mimics those in bacteria, adjusting to fluid dynamics relative to the scale in which the diatoms live (Medlin, 1991). Increased density and type of epiphytes were found in highly branched host plants (Bryocladia) vs. flat, unbranched host plants (Gelidium) (Medlin et al., 1985). Epiphytes usually prefer the edges of macrophytic host plants (Cattaneo, 1978; Siver, 1980; Van den Ben, 1969) but in high velocity area, epiphytes preferred the lamina of the host (Van de Ende and Haage, 1963).

The epiphytic community responds rapidly to environmental factors. Main and McIntire (1974), working in Yaquina Estuary, Oregon and Sullivan (1977), working in Mississippi found most community differences were in the winter and in host plant position in the intertidal zone. Hoagland et al. (1982) suggested seasonal features dominated community changes. Hopkins (1964) and Godward (1934) found that most epiphyte species, i.e., Cocconeis spp., preferred low light, whereas Edsbagge (1966) found that Achnanthes and Licmophora preferred high light and high temperatures and that the epiphytic community reached its maximum as hosts declined. He also noted a strong response to salinity and in the Baltic, true marine species were only found at depth. The upper littoral communities between Sweden and the UK were similar but the sublittoral community in Sweden corresponded to the lower littoral community in the UK (Aleem, 1949). Zonation was also reported by Simonsen (1962). Nutrient availablility and its influence on epiphytes attached to seagrasses were studied by Frankovich et al. in two studies (Frankovich et al., 2006, 2009). In the first study, differences in the spatial and temporal structure of the diatom community were documented by multivariate analyses and in the second study, the response of the diatom community was studied with field manipulations $\mathrm{N}$ and $\mathrm{P}$ additions. Additions primarily affected the macroalgal epiphytes and decreased the micro-epiphyte communities and their only increased response to $\mathrm{P}$ addition occurred in the summer. Nutrients strongly structure epiphyte species composition as compared to controls that were non-enriched (Marks and Power, 2001). However, other factors, such as salinity, may override any effects of nutrient limitation (Snoeijs, 1999). Letákováé et al. (2018) suggested that the mode of attachment implied tolerance of certain nutrient and environmental conditions. For example, low lying forms (adnate species) were likely tolerant of the poorest conditions, whereas motile forms are able to optimise their positions relative to abiotic conditions around the host plant.

The epiphytic diatom community offers an excellent system to study attachment mechanisms and community changes in response to both biological and physical factors. Teasing out the biological factors from physical ones can be difficult. We first addressed biological factors: the host plant, its shape or type and then physical factors: the host plant's position in the intertidal (exposure), salinity and seasonality over a two year period along the Texas coast of the Gulf of Mexico.

\section{Material and methods}

\subsection{Description of the study sites}

\subsubsection{Jetty system}

The Texas coast of the Gulf of Mexico is characterised by a series of barrier islands, which front extensive drainage basins or bay systems (Fig. 1). Six basins occur along the Texas coast: Galveston, Matagorda-Brazos, San Antonio, Copano-Aransas, Corpus Christi, and Laguna Madra (Shew et al., 1981). Of these, Galveston, Copano-Aransas and Laguna Madra were chosen as collecting sites (Fig. 1) because they are located in the upper, mid and lower regions of the Texas barrier island system and represent a transition from a humid (Galveston) to a semi-arid climate (Laguna Madra) with the Copano-Aransas system as a median point.

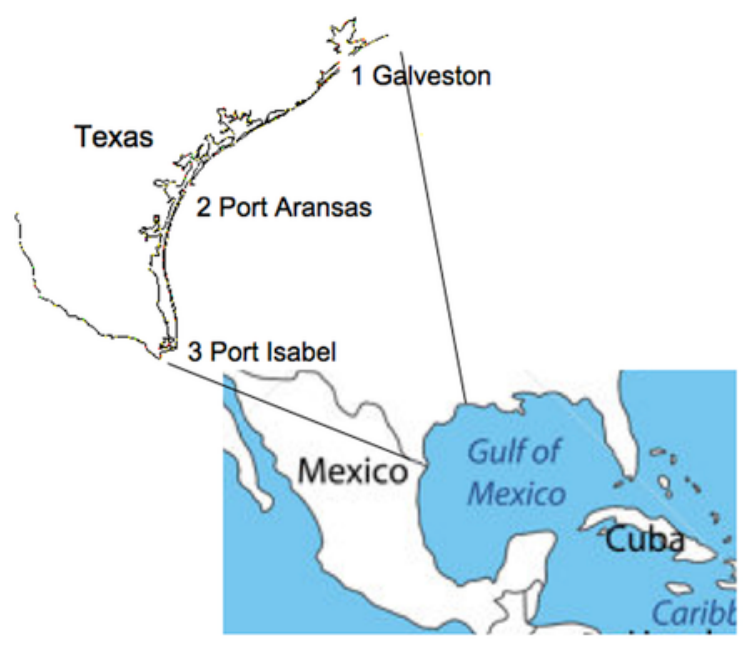

Fig. 1. Map of the 250 mile coastline of Texas showing the three collection sites. Larger map shows the Gulf of Mexico in relation to Mexico and Cuba. 
Sediments are carried into the three bay systems by their associated rivers, with Galveston Bay having the largest load and Copano-Aransas and Laguna Madre ranking 5th and 6th, respectively, out of all the Texas basins, making the basins very silty. Mississippi River sediments are carried southward but their effect is greatly diminished once the plume passes Galveston Island. The Gulf of Mexico has a silty sandy bottom and the only other natural substrates for macroalgal attachment would be oyster reefs and wooden piers, which are more common in the bay systems behind the barrier islands. Pink granite block jetties have been constructed seaward at natural passes between barrier islands to maintain open, dredged routes for shipping and offer the only hard substrate other than pilings and oyster reefs for macroalgal attachment. Each block is approximately $1 \mathrm{~m}^{2}$ and they are stacked about $2 \mathrm{~m}$ tall. The tops of the jetties are not normally submerged. A substantial macroalgal flora is present on the jetties at each study site (Edwards, 1970).

\subsubsection{Salinity}

There is a salinity gradient along the Texas coast. Precipitation along the Texas coast decreases southward, with a bimodal distribution in spring and fall until at Laguna Madra where a single late summer peak is noted (Shew et al., 1981). The N-S precipitation gradient and associated gradient in river discharge affects the salinity of the near shore waters creating a natural gradient along the coast. Surface salinity was determined with a refractometer at each sampling.

\subsubsection{Temperature}

Galveston is the coolest of the three sites (annual average $21^{\circ} \mathrm{C}$ ) and has a growing season of ca. 265 days, whereas in the lower Laguna Madra the air temperature in warmer throughout the year at $23^{\circ} \mathrm{C}$ and a growing season of 330 days (Shew et al., 1981). Water temperatures follow air temperatures because the waters are so shallow as a result of the wide continental shelf in this part of the Gulf of Mexico. Because of the wide water temperature range characteristic of the Texas coast, a warm temperate macroalgal flora is present. When water temperatures are high, a tropical flora of Caribbean affinity dominates. As temperatures drop, the tropical floras are replaced by cool temperate forms of North Atlantic affinity (Edwards \& Kapraun 1973). Water temperatures were measured with a mercury thermometer.

Temperature and salinity measurements taken by the National Ocean Survey/NOAA were used to obtain changes in water temperature and salinity for the two week period prior to each collection date.

\subsubsection{Tides and winds}

Tides along the Texas coast are mixed diurnal with a very small tidal range (11 cm. Galveston, $25 \mathrm{~cm}$ Copano-Aransas, $15 \mathrm{~cm}$ Laguna Madre) (Shew et al., 1981). These ranges vary by season (winter minimum and fall maximum) and with the passage of major weather storms (hurricane and tropical storms). Maximum tidal range $(1.2 \mathrm{~m})$ was found during the spring at all sites. Even with this small tidal range, there is a distinct intertidal range and a macroalgal zonation (Edwards, 1970). The macroalgae in the high intertidal are not submerged in the water except by wave action and extremely high tides and are exposed to high light intensity at all times.

All samples were taken on the date for the lowest tide that month every two months. Wind patterns are prevalently south-easterly to southerly and modify the tidal range, with northerly winds maximising it and the exposure of the macroalgae and its epiphytes. Most wind effects were noted in the winter when strong northerly winds pushed the water away from the jetties exposing the low intertidal. This exposure usually lasts a few days until the cold front passed.

\subsection{Sampling strategy}

Diatom samples were collected at two month intervals from September 1977 to July 1979 from selected macroalgae attached to jetties at Galveston, Port Aransas, and Port Isabel, Texas (Fig. 1, Table 1). During year one, a wide variety of host plants were sampled based on shape differences, intertidal position, and availability at all three sites as a survey prior to year two (Medlin, 1983). Although several plants could be collected year-round, many were replaced by a Porphyra dominated winter community. In the second year, only those hosts that could be collected year-round were sampled and collected in triplicate. Replicates were taken approximately $30 \mathrm{~m}$ apart at all locations, with replicate 2 being sampled at the same location where all plants were collected in year one. All samples were refrigerated until processed.

All host plants were processed as follows: each was cut in half and examined separately to determine if the diatom community differed

Table 1

List of all host plants and their location at each site for the first sampling year. Those highlighted in bold were collected in triplicate for the second year.

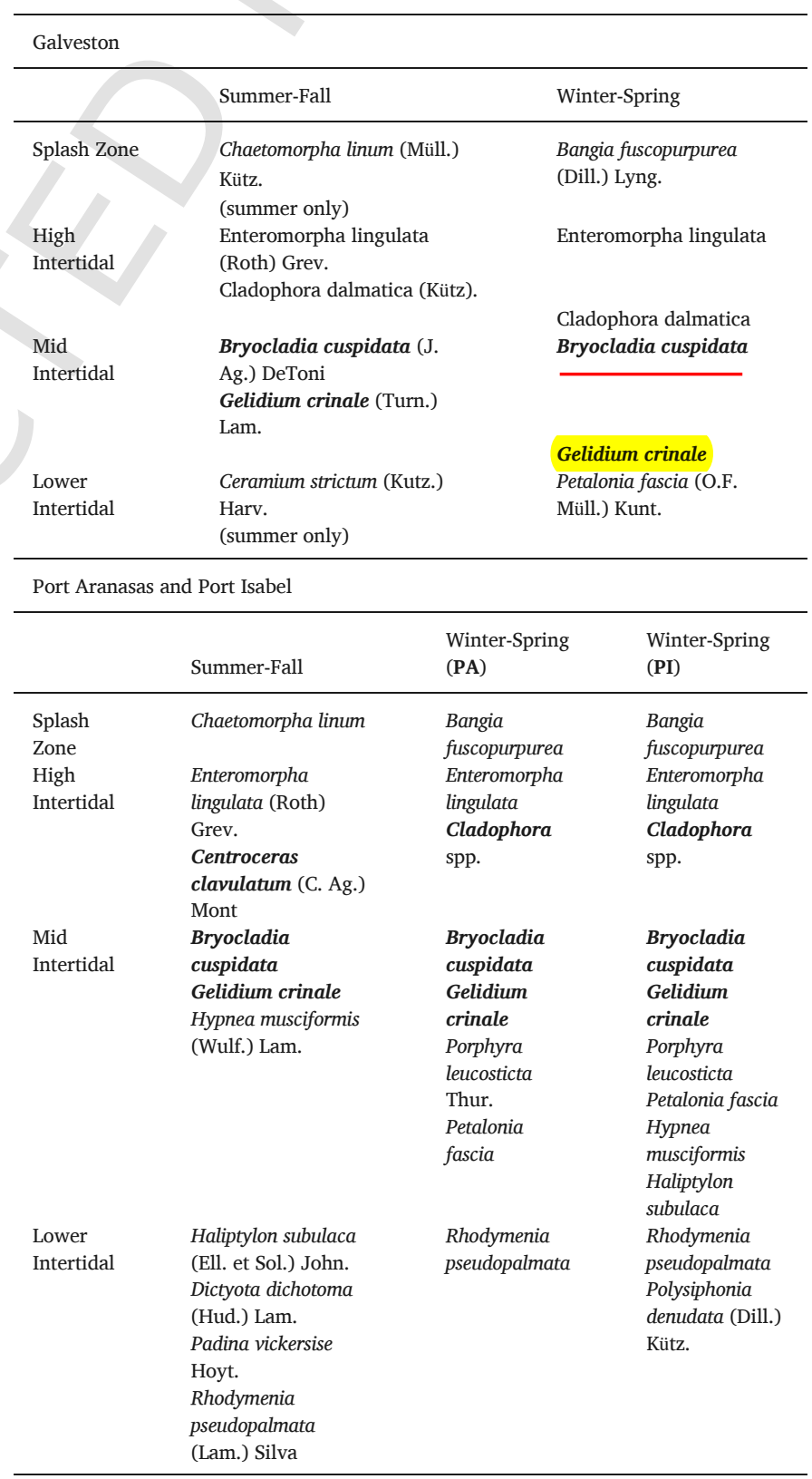


from tip to base of the macrophyte (Fig. 2). Tips and bases of the host plants were placed in separate containers and gently manually agitated for 30 s to remove the metaphyton from the epiphyton. Tips and bases of the host plants and their respective washes were cleaned of organic matter with saturated permanganate and hydrochloric acid (Simonsen 1984). Permanent slides were made in hyrax. 500 valves were counted from the tip and base preparation of each host plant. 250 valves were counted from the tip wash and from the base wash and pooled to represent a single wash sample because in some samples, 500 valves could not be counted in each wash. Counts were made only from those plants collected in the first year that were collected in triplicate the second year and for September, January and May for the two years. Each taxon was photographed with a Zeiss standard $\mathrm{K}$ microscope equipped with Nomarksi and Phase Contrast optics and given a unique reference number (Figs. 3 and 4, Table S1).

\subsection{Community composition parameters}

A variety of parameters were calculated to characterise the community (Table 2). Diversity (H") is a biased estimate of the community computer parameter H' (Pielou, 1975), but the bias is negligible at sample sizes of 500 counts (McIntire and Overton, 1971). Redundancy (REDI) measures the relative degree of species dominance or evenness it a sample (McIntire and Overton, 1971). Resemblance measures detect the degree of similarity between any two samples and were measured by two indices (SIMI and DIFF). SIMI gives more weight to abundant taxa, whereas DIFF weights rare taxa. These statistics compared: tips to bases of the same host plant to determine vertical zonation, the metaphyton to the epiphyton, replicate host plants for within host differences, site and year differences. Niche breadth $\left(B_{j}\right)$ of each taxon is an indication of the ability of a taxon to do equally well at all sites or host plants an $d$ is not necessarily related to its total relative abundance in all samples. High $B_{j}$ values would be predicted for species that do not discriminate between host plants, whereas low values would suggest host specificity. The diversity and redundancy measures were calculated using the AIPONE program; the similarity, difference and niche breadth measure were obtained with the AIDN or AIDNX program at Oregon State University. Because of the constraints of the AIDN or AIDNX program regar ding maximum number of blocks to be compared, the samples were pooled as follows:

1) to compare treatments (wash, tip and base) within host plant, each ite for each year was examined separately

2) to determine within host plant variation, the three treatments of fach host plant collected during the second year were pooled to repnesent a composite count for one replicate of the entire host plant. Replicate host plants were then compared. In the first year only one

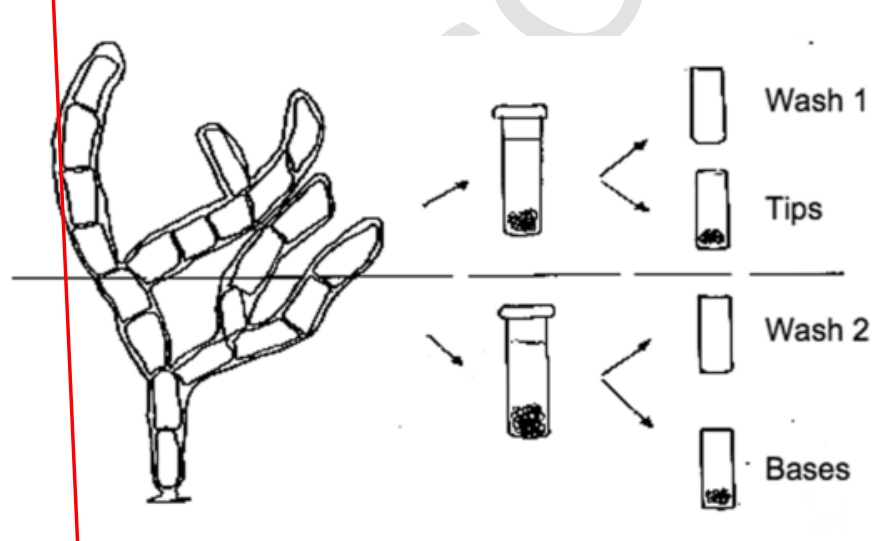

Fig. 2. Scheme showing the treatment of each host plant for processing of the associated diatom flora.
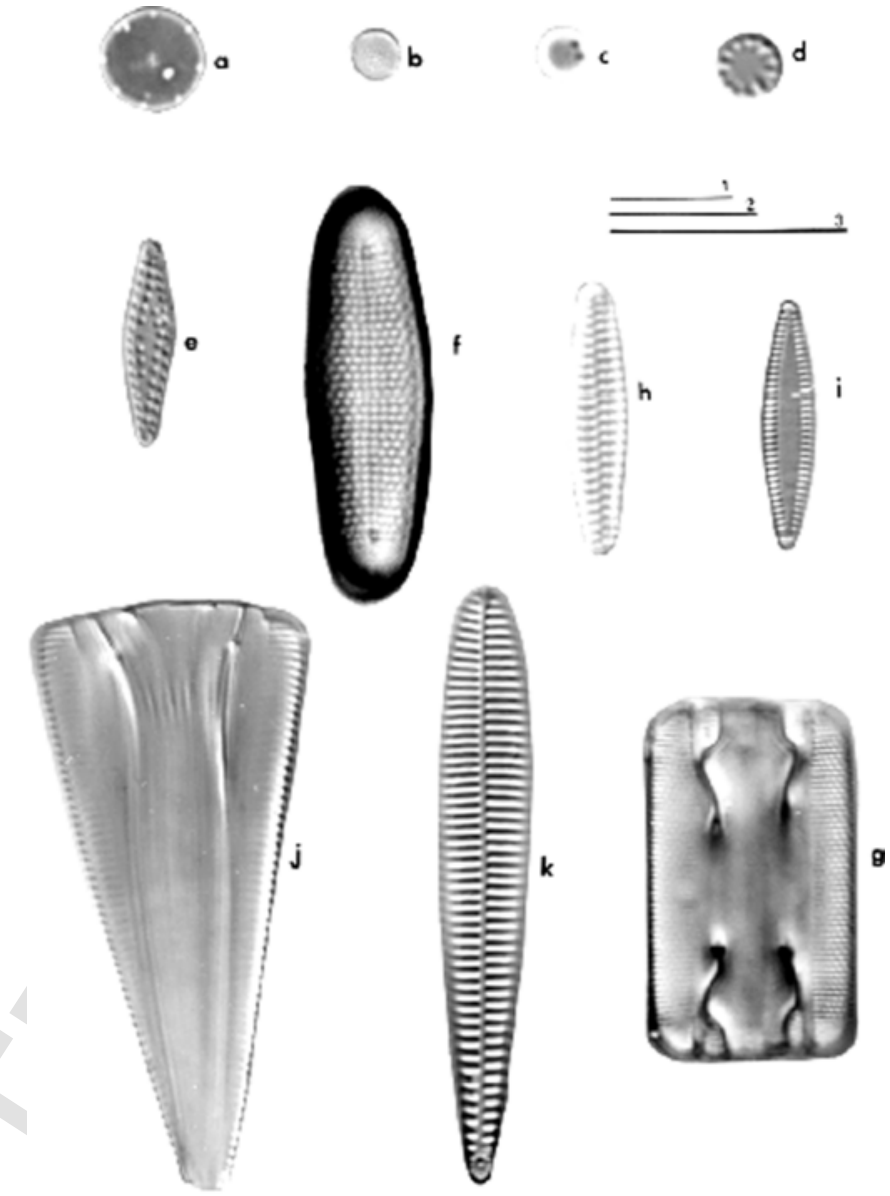

Fig. 3. Light micrographs of the most abundant centric and araphid diatoms in the study. Scale bar $=10 \mu \mathrm{m}$. Scale 1 for a,b,e-g, i-k. Scale 2 for c,d. a. Thalassiosira cf. profunda, b. small lineate Thalassiosira sp., c. Minidiscus sp., d. Cyclotella atomus, e. Cymatosira belgica, f. Grammotophora oceanica valve view, g. G. oceanica girdle view, h. Neodelphineis pelagica, i. Tabulata tabulata, j. Licmophora abbreviata girdle view, k. L. abbreviata, valve view.

replicate was taken and the same pooling was done to obtain a composite count for the entire host plant and compared to the second replicate, which was taken at the same site as the single replicate in year one.

3) to determine within year variation, samples collected at the three sites the first year were compared together, whereas those collected the second year were compared together. In the second year, the three treatments representing a single host plant for all three replicates were pooled to form a composite count for the entire host plant, and host plants were compared.

4) to determine between year variation, all samples collected at three sites the first year were compared only to those samples representing the second replicate collected at the three sites during the second year. The second replicate was chosen because it corresponded to the site where all of the samples were taken the first year.

Analysis of variance with a Duncan's multiple range test was performed to test the difference between the means of the SIMI values when the data were pooled by treatment and by plant.

\subsection{Multivariate analysis}

Multivariate analyses are mathematical tools that reduce variation in the community composition and in species relative abundance into identifiable patterns and relate these patterns to environmental vari- 

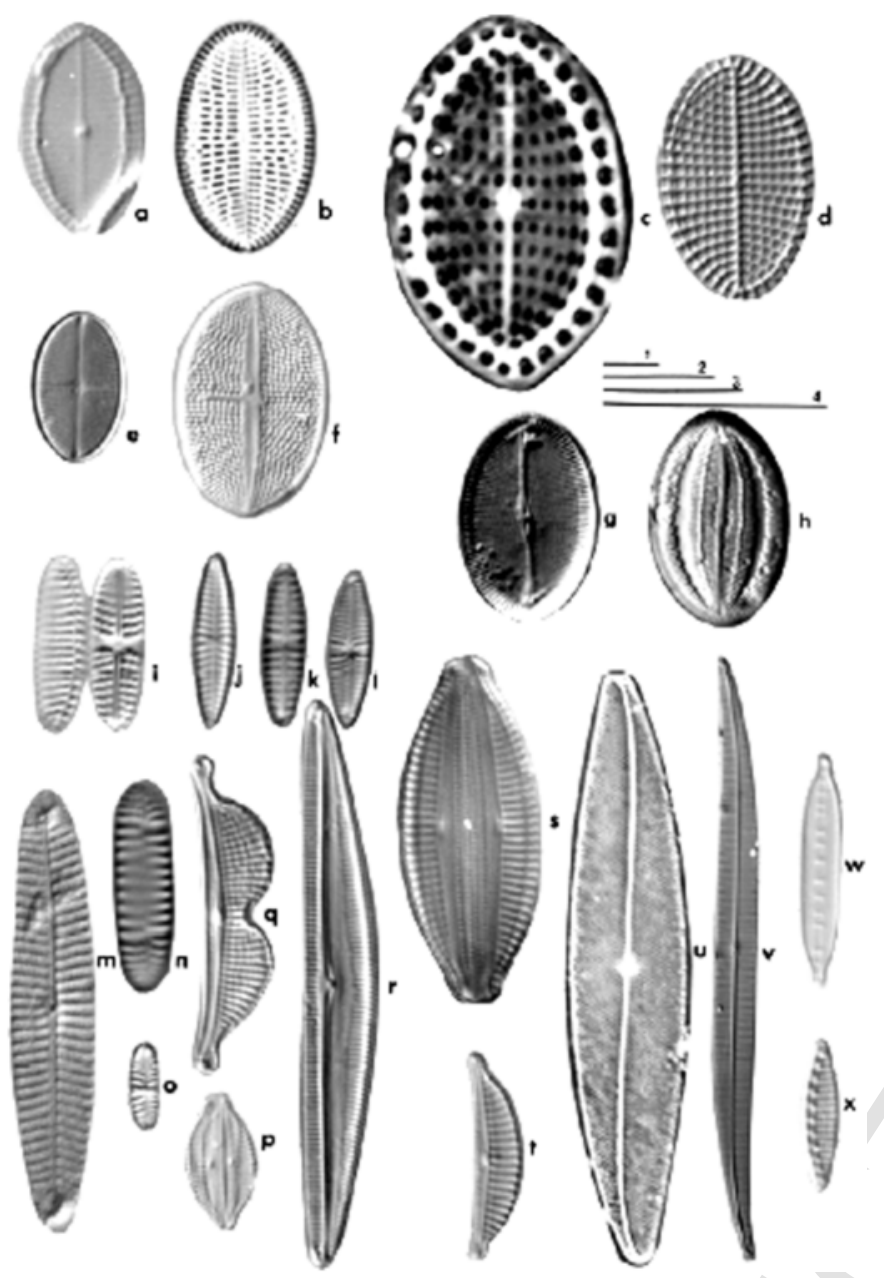

$\operatorname{Max} \mathrm{H}^{\prime \prime}$

Summary of the community composition parameters used in this study and their definition and explanation of their use.

Diversity $\mathrm{H}^{\prime \prime} \quad \mathrm{H}_{\mathrm{j}}^{\prime \prime}=-\sum_{\mathrm{i}=1}^{\mathrm{S}} \mathrm{P}_{\mathrm{i}} \log _{2} \mathrm{P}_{\mathrm{i}}$
proportion of the ${ }_{i}$ th species in the ${ }_{j}$ th sample and $S$ is the total

number of species in the sample. $\mathrm{H}^{\prime \prime}$ is a biased estimate of the community computer parameter $\mathrm{H}^{\prime}$ (Pielou, 1975), but the bias is negligible at sample sizes of 500 counts

(McIntire and Overton,

1971). Based on the observed number of species in each sample, a conditional maximum and minimum diversity from that sample can be calculated. Where S and N are the number of species and individual in that sample,

Fig. 4. Light micrographs of the most abundant raphid diatoms in the study. Scale bar $=10 \mu \mathrm{m}$. Scale 1 for u,v, Scale 2 for a-j, 1, m, o-t,w, Scale 3 for n,x, Scale 4 for k. a. Cocconeis placentula var. euglypta raphe valve, b. rapheless valve, c. Cocconeis scutellum, raphe valve, d. rapheless valve, e. Cocconeis cf. dirupta raphe valve, f. rapheless valve, g. Cocconeis littorale, rapheless valve, h. raphe valve, i. Achnanthes brevipes v. intermedia, j. Navicula agnita, k. Navicula diserta, 1. Navicula comoides, m. Navicula stompsii, n. Rhoicosphenia adolfi, diminished raphe valve, o. raphe valve, p. Amphora tenerrima, q. Amphora bigibba, r. Amphora cymbelloides, s. Amphora acutiuscula, girdle view, t. valve view, u. Pleurosigma barbadense, v. Gyrosigma sp. 1, w. Nitzschia incrustans, x. Nitzschia frustulum.

ables. By reducing the community dimensionality, biological interpretation of the organisation (arrangement of sites or species to environmental gradients) is often possible (Gauch et al., 1977). We quantified the pattern of variation and magnitude and significance of diatom response to explanatory variables (spatial variation, host type, treatment type, and season) using redundancy analysis (RDA), a form of constrained principal components analysis. We used RDA with location as a single constraining variable to summarise community variation between sites and partial RDAs and variance partitioning (Borcard et al., 2011) with either location, treatment, season and host type as constraining variables and the remaining variables as co-variables to quantify the relative importance of each explanatory variable at each location. The significance of each variable was assessed using a Monte Carlo permutation test. Diatom relative abundance data was square-root transformed prior to analysis to yield ordinations based on Hellinger's distance, which is appropriate for examining community differences in species data that show non-linear, unimodal responses (Legendre and Gallagher, 2001). For constant sum data such as ours, an RDA of Hellinger-transformed data will give an ordination similar to canonical correspondence analysis (CCA) but avoids the problems that

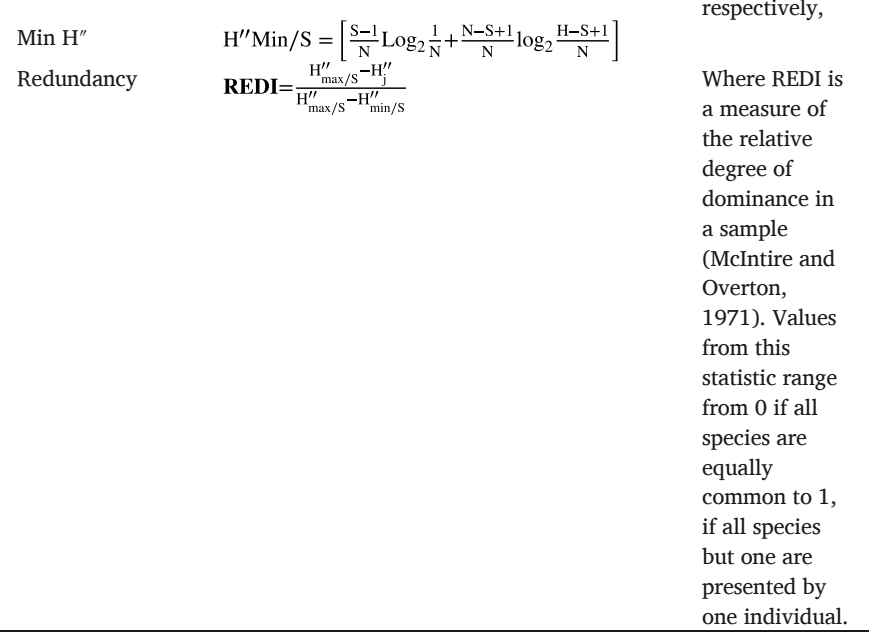




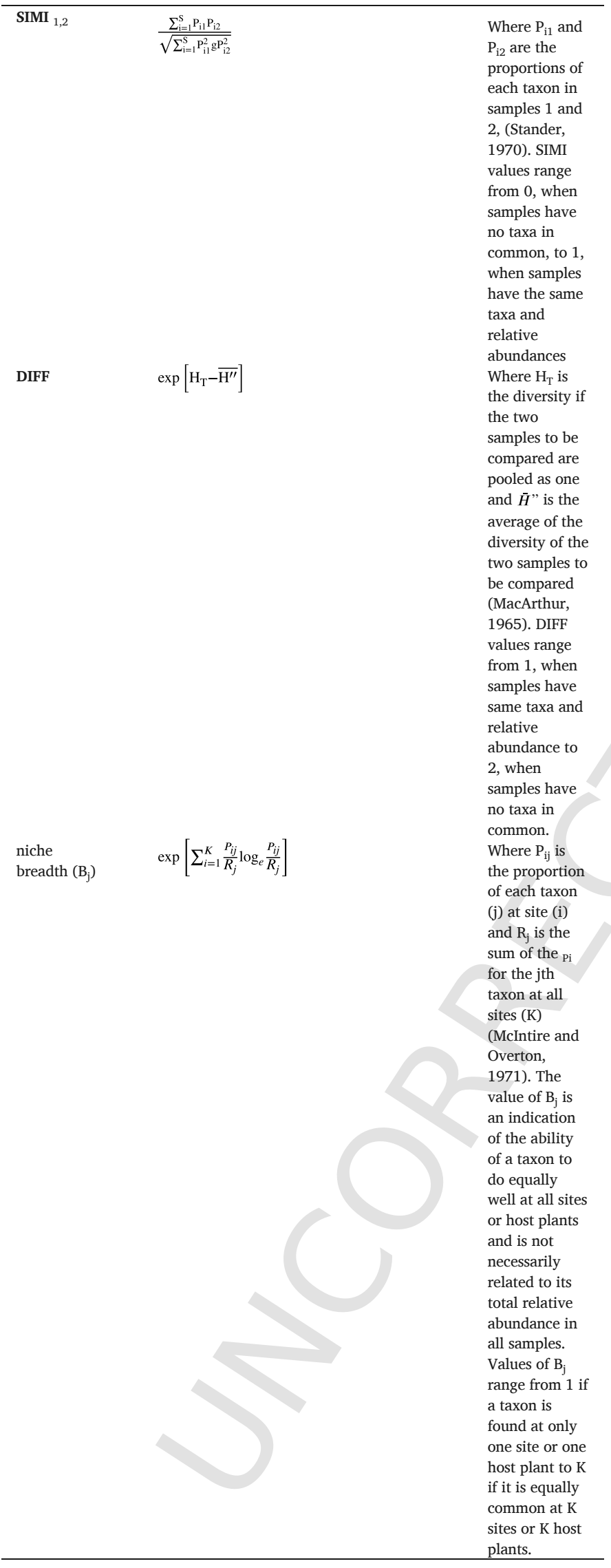

CCA has with unusual or extreme site/species combinations. All statistical analyses were performed using $\mathrm{R}$ software for statistical computing and graphics (R Core Team, 2017) and the vegan package (Oksanen et al., 2017).

\section{Results}

\subsection{Abiotic changes over the sampling period}

Salinity values for the sampling period ranged from 19 to $35 \%$ oo at Galveston, from $22 \%$ oo to $38 \%$ oo at Port Aransas and from $28 \%$ oo to $38 \%$ oo at Port Isabel (Fig. S1); being related to the freshwater input at each basin. Lowest salinity values were in May and in the second year, the salinity values at all sites were clearly more variable (see red circle in Fig. S2) and overall salinity ranges for the year were lower. Port Isabel was hypersaline for several months during the summer.

Water temperature for the sampling periods ranged from $7.7^{\circ} \mathrm{C}$ to $31^{\circ} \mathrm{C}$ at Galveston from $7.7^{\circ} \mathrm{C}$ to $30^{\circ} \mathrm{C}$ at Port Aransas and from $11.5^{\circ} \mathrm{C}$ to $28.8^{\circ} \mathrm{C}$ at Port Isabel (Fig. S2). The three sites mirrored each other in their variability with the lowest temperatures being in January.

\subsection{Responses to physical shape of the host plants}

During the first year, macroalgae representing various taxonomic groups, thallus shapes and intertidal location were collected (Table 1). Although cell counts were made only from selected species of these host plants (Table 1), observations were made on the abundance and distribution of epiphytic taxa on all hosts collected in year one (Medlin, 1983). From these collections, three host shapes were selected for a more in-depth analysis in the second year from two intertidal locations (Table 1), which included replicates taken at the beginning, middle and end of the jetty, ca. $30 \mathrm{~m}$ apart. It was not possible to collect the same type of plant shape from the same intertidal location. Thus, filamentous host plants were collected from the high intertidal and the other two host plant shapes from the mid intertidal. Three basic host plant shapes were collected: highly branched filamentous, cylindrical with many branchlets, flattened cartilaginous with few branches. Illustrations can be found in Medlin (1983) and in Medlin et al. (1985) where the zonation and the density of the epiphytes per unit area of the host plant were documented in detail.

Cladophora dalmatica (Chlorophyta), Cladophora vagabunda (Chlorophyta) and Centroceras clavulatum (Rhodophyta) were hosts that represented a filamentous highly branched growth habit. Cladophora dalmatica or vagabunda, collected year round in Galveston and during the spring in Port Aransas and Port Isabel, was replaced by Centroceras clavulatum during the fall and winter at Port Aransas and Port Isabel. Centroceras and Cladophora were treated as the same host plant shape because they both occurred in the high intertidal and both were filamentous. These three host plants were found only in the high intertidal zone where they were exposed to the highest exposure not only to light intensity but also were generally continually exposed and vulnerable to desiccation. Diatoms preferred to settle in the forks of the branches or in the inner surfaces of the many branchlets of these host plants (Medlin et al., 1985). Cocconeis spp. were noticeably missing or reduced in numbers at the bases of these plants.

In the mid intertidal, the host plants, Bryocladia and Gelidium, could be collected from all three locations for both years. They were exposed only during the lowest tides and were present year-round at all three sites. Bryocladia cuspidata (Rhodophyta) represented a gelatinous cylindrical shape with many small branchlets, much like a pipe cleaner. The diatom community on Bryocladia was prolific, appearing as brown fuzz more highly concentrated at the host plant tips. The species on the branchlets were different from those attached to the main axis of the plant (Medlin et al., 1985). The spiral arrangement of the branchlets 
along the main axis offered a trap for settling silt particles and diatoms belonging to the metaphyton, viz. Thalassiosira and Navicula spp. Gelidium crinale (Rhodophyta) was a cartilaginous macroalga with a cylindrical to flattened shape with few branches, thus presenting larger flat areas for epiphyte colonisation and was commonly epiphytized by Cocconeis spp. (Medlin et al., 1985). Large areas of the host plant thalli were visibly devoid of any epiphytes. Stalked species, such as Rhoicosphenia adolfi and Grammatophora oceanica, were only concentrated within forks and wound areas of its thallus.

\subsection{Analysis of the epiphyte distribution using community composition parameters supported by multivariate analyses}

\subsubsection{Abiotic factors}

Reciprocal Averaging techniques in 1983 for the initial analysis of these data required that all host plant treatments be pooled because of limited computer capacity (Medlin, 1983). That analysis documented a continuum from Galveston to Port Isabel (Medlin, 1983, Fig. S3). The first axis in Medlin (1983) was a geographical axis moving from Galveston on the left to Port Isabel on the right. Regression of the sample rankings from the first axis against salinity (taken on the day of sampling and the average for the two weeks prior to sampling) explained $16 \%$ of the variation, Seasonal differences were detected moving from left to right within each site, except for Port Isabel which was more homogenously mixed. Similar analyses with temperature showed that it was not significantly correlated with sample rankings.

This continuum is not as clearly shown in the present RDA analysis, Redundancy analysis with location as a single explanatory variable (acting as a surrogate for salinity) clearly and significantly $(\mathrm{p}<0.01)$ separated the three sites (Fig. 5A). Galveston is to the left, with Port Aransas at the bottom right and Port Isabel top right of Fig. 5A. Species preferentially recovered at Galveston were Tabularia tabulata, Licmophora abbreviata, Navicula sp. 20 with Grammatophora oceanica and Licmophora gracilis $v$. anglica overlapping into Port Aransas (Fig, 5B). Port Aransas species were Cocconeis dirupta v. flexella, Rhoicosphenia adolfi, Cocconeis scutellum, Navicula comoides, Thalassiosira cf. profunda, Navicula sp. 120, which also were abundant at Port Isabel. Port Isabel species were tightly clustered about the cluster centroid, with only Nitzschia frustulum distinctly removed from the centroid at this site. Variance partitioning shows that location accounts for approximately $10 \%$ of the variation. Seasonal differences (6\%), treatment (6\%) and

Location - Galveston - Port Aransas + Port Isabel

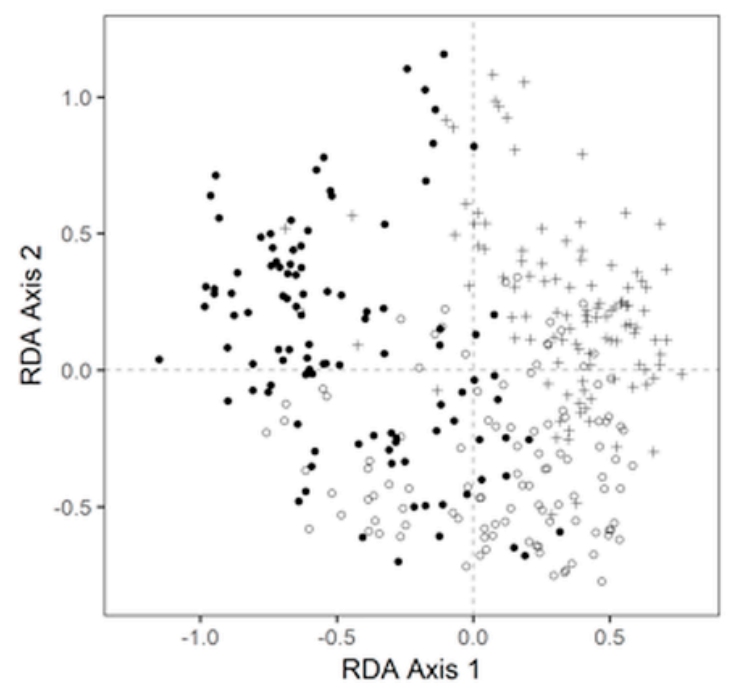

host type (4\%) account for significant but smaller fractions of the variation (Table 2).

\subsubsection{Diversity and relative abundance}

The epiphytic diatom community contained a total of 351 taxa, representing 68 genera, Table S1). The majority accounted for less than $20 \%$ of the cells present and were usually represented by 5 or fewer individuals in any one sample. The most commonly encountered taxa for the two year sampling period, respectively, were Rhoicosphenia adolfi (20\%, 27\%, code 100), Navicula diserta (11\%, 10\%, code 232), Cocconeis scutellum (9\%, 6\%, code 111), Grammatophora oceanica (6\%, 8\%, code 62), Navicula stompsii (4\%, 5\%, code 234$)$, Nitzschia frustulum (4\%, 4\%, code 544), Tabularia tabulata (3\%, 5\%, code 72), Thalassiosira cf. profunda (5\%, 3\%, code 56), Licmophora abbreviata (7\%, 1\%, code 77) Cymatosira belgica (4\%, $2 \%$, code 12$)$, Navicula comoides $(2 \%, 3 \%$, code 238), Amphora acutiuscula (2\%, 2\%, code 460), lineate Thalassiosira sp. (1\%, $2 \%$, code 14), Thalassiosira cf. profunda (1\% 1\%, code 25), Achnanthes brevipes v. intermedia ( $1 \%, 1 \%$, code 103$)$ Cocconeis placentula $(1 \%$, $1 \%$, code 113$)$, Cocconeis woodii (1\%, 1\%, code 117$)$, and are illustrated in Figs. 3 and 4. Thalassiosira cf. profunda is a small centric, diameter 7-8 $\mu \mathrm{m}$ with 4-5 marginal strutted processes and one central strutted process. When samples abundant in this taxon were examined with SEM, several other small centrics of this size range were encountered, although not as abundant as Thalassiosira cf. profunda. Because of the silt common to all of the samples, the image of this diatom was often partly obscured and it is likely that counts of this species may contain other species, although based on SEM observations they were not abundant.

These taxa, plus 34 others, accounted for over $90 \%$ of the valves counted. Most rare taxa encountered were in the wash where presumably they were deposited within the branches of the host plant and were primarily from the epipelic community. Chaetoceros spores were also common, especially in the second year at Port Isabel.

\subsubsection{Separation by treatment}

(Figs. 6 and 7B, Table 3, Table S2, Fig. S4). If the data are pooled by treatment for each site, the diversity, redundancy and taxon niche breadth $\left(\mathrm{B}_{\mathrm{j}} \mathrm{B}\right)$ in each treatment can be compared. Niche breadth ranged from one, if the taxon was present only in one treatment to 3 if it was found in all three treatments pooled across the three sites. $\mathrm{B}_{\mathrm{j}}$ val-

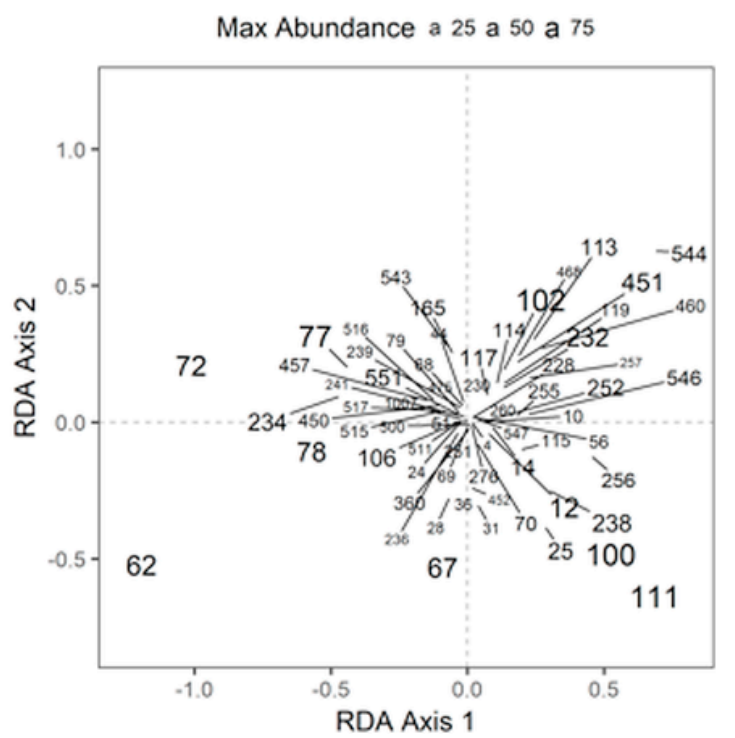

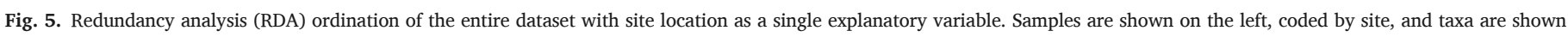
on the right, with size scale by maximum relative abundance. See Table S2 for taxon codes/names. 

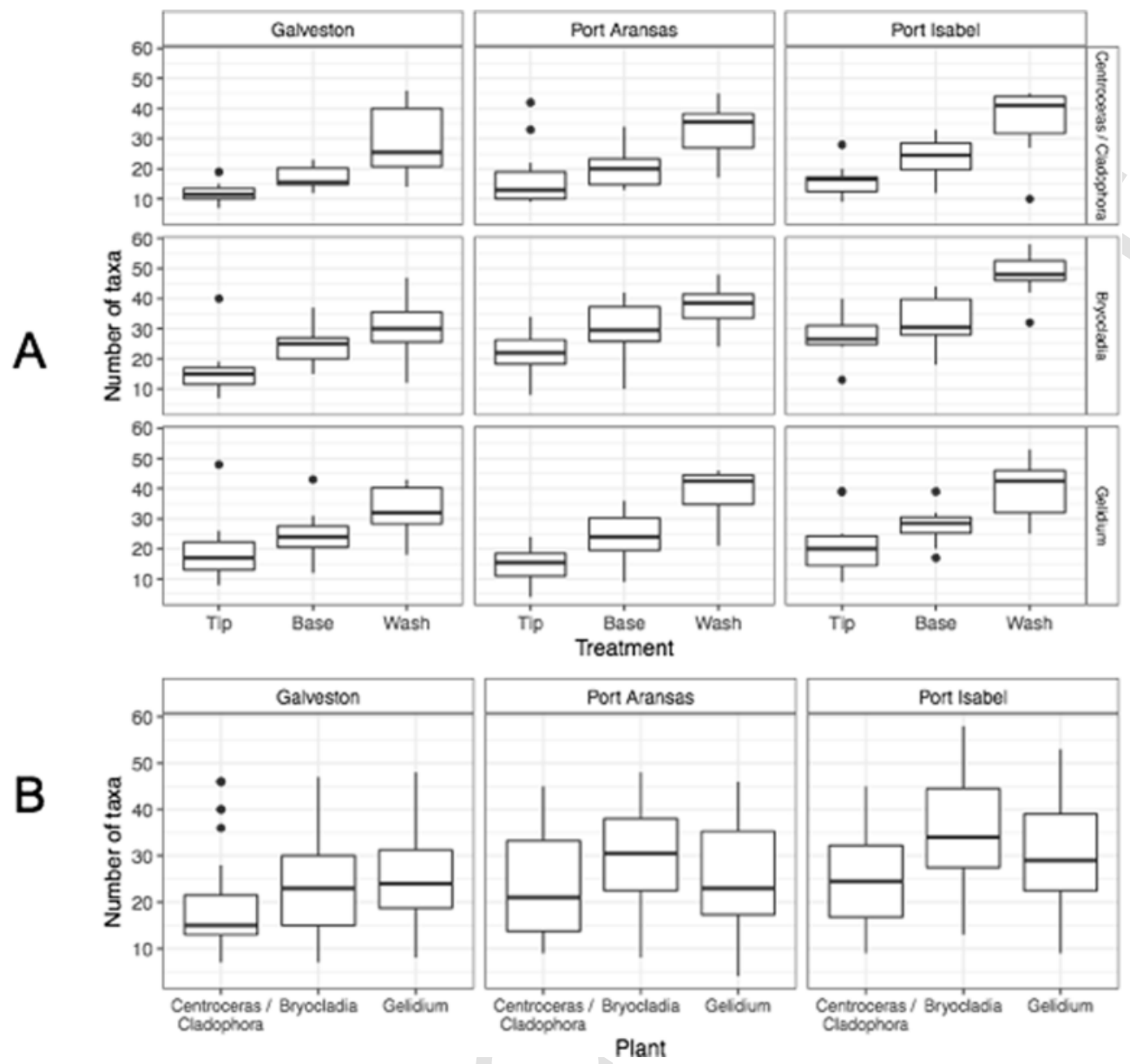

Fig. 6. Box plots showing diversity (number of taxa) as a function of (A) treatment by host type and location, and (B) host type for each location.

ues are not necessarily related to total relative abundance in all samples.

The diversity within the individual treatments of each host plant was more variable than that between host plants. The wash usually had one to four times more taxa than either the tips or the bases making it more diverse than the other two treatments (Supple. Fig. ¥). For Cladophora dalmatica/vagabunda and Centroceras clavulatum, the wash was more diverse at Galveston than at Port Aransas/Port Isabel. The same diversity pattern was common on Gelidium crinale, but the number of wash taxa usually ranged from one to two times that found on the tips and bases. On Bryocladia cuspidata, the entire diatom community was more abundant than on the other host plants but the diversity on this host plant was not greatly different between treatments. Although there was a general increase in diversity from tip to base of the plant, the number of taxa on the tips and bases was more similar in Port Isabel. Overall Port Isabel was more diverse than the other two sites.

Certain taxa, such as Thalassiosira cf. profunda, and the small lineate Thalassiosira sp., were more common in the wash but were also found on the host plant. These planktonic taxa have been trapped within the branches and continued to thrive there. Cymatosira belgica can be found not only in the plankton but also in the sediments and should be considered tychoplanktonic. It was easily washed off the host plant, probably from the base of the plant where it was more numerous. These taxa had a niche breadth $\left(\mathrm{B}_{\mathrm{j}} \mathrm{B}\right)$ of $2.03,2.21$, and 2.56, respectively. These and other less numerically important ones, such as Pleurosigma spp., Gyrosigma spp. and many of the Navicula spp., such as diserta, are major metaphyton on the hosts. Choanoflagellates were also seen in the wash.
Metaphytic taxa (wash) were most abundant on Bryocladia and Cladophora/Centroceras.

Species more abundant on the plant tips were Achnanthes brevipes v. intermedia, Cocconeis scutellum, Grammatophora oceanica and Licmophora abbreviata with $\mathrm{B}_{\mathrm{j}} \mathrm{B}$ of $2.69,2.35,2.7,1.97$, respectively.

Taxa more commonly found in greater abundance at the base of the plants were Navicula comoides and Nitzschia frustulum. In Galveston, $N$. frustulum was more common on the bases or in the washes of the plants, but in Port Isabel, it was increasingly more important numerically and more equally distributed throughout the treatments $\left(B_{j} B\right.$ changed from 2.64 to 2.95 from Galveston to Port Isabel). Amphora acutiuscula and A. tenerrima were more prevalent at the base of the host plants in Galveston and Port Aransas. Their abundance and distribution increased and spread more to the tips of the plant at Port Isabel. Their lower abundance in the wash reflected their means of attachment to the host plant.

Tabularia tabulata was quite abundant in Galveston in all treatments (2.53) but decreased in abundance southward, especially in year 2, where it was slightly more abundant on the base of the host plant (2.17). Rhoicosphenia adolfi, Navicula diserta and Navicula stompsii were equally distributed throughout the wash, tips and bases of the host plants $\left(\mathrm{B}_{\mathrm{j}} \mathrm{B}=2.8,2.93,2.9\right.$, respectively).

Redundancy measurements (REDI) compare the overall dominance in the diatom community by a few species. Values higher than 0.6 were more frequently encountered on Cladophora dalmatica and Centroceras clavulatum than on the other two host plants (Table 3, Figs. S4C and S5) where values over 0.6 were usually encountered on the tips rather than the bases or the washes, indicating that on those host plants there 

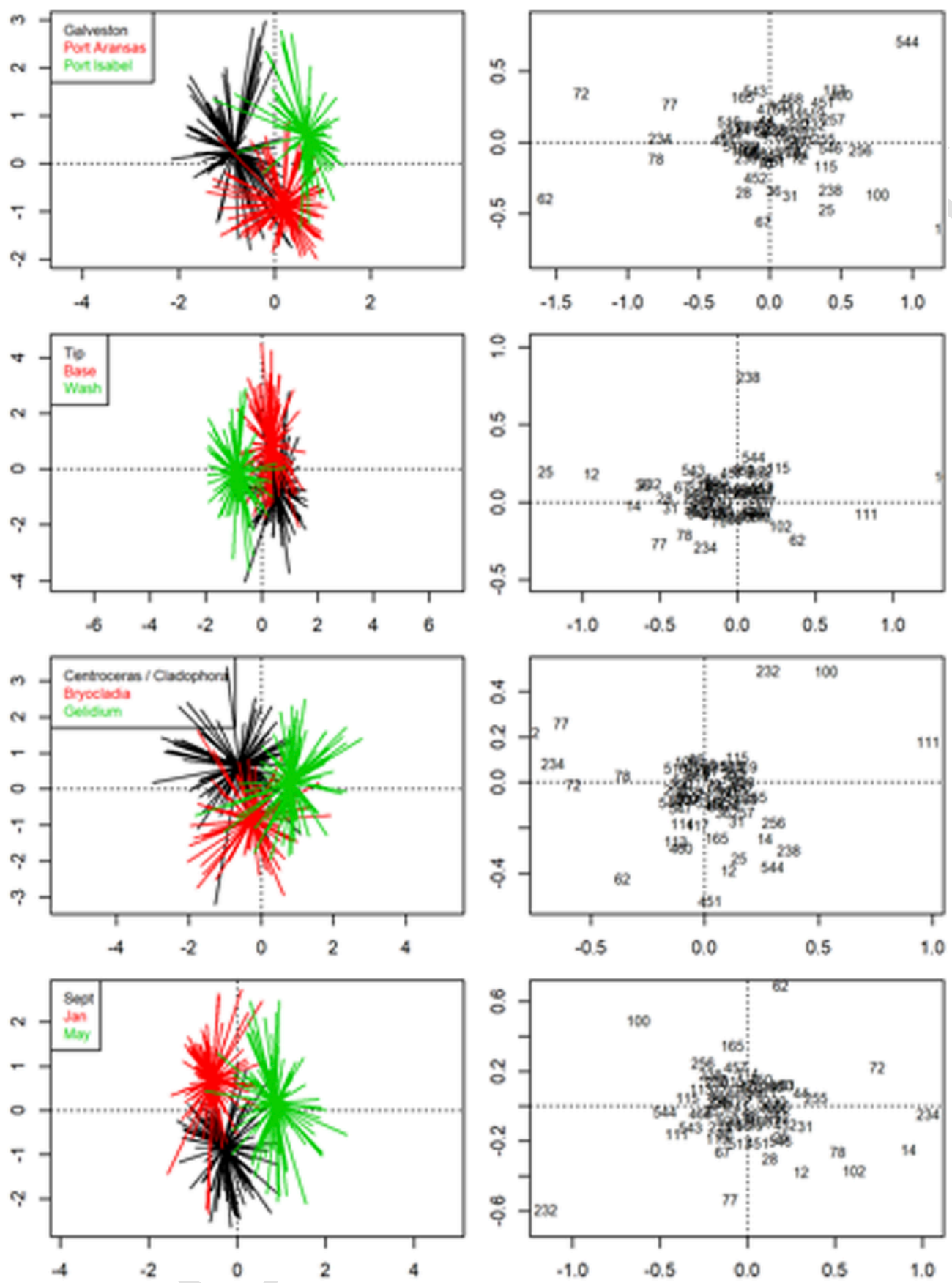

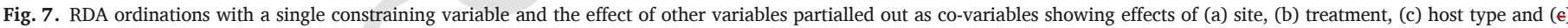

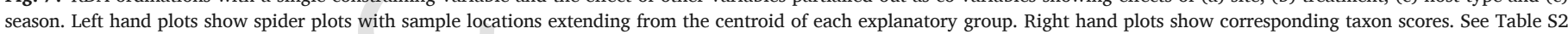
for taxon codes/names.

was a tendency for just a few species to dominate the community on the tips. The same diversity pattern as seen for the high intertidal host plants was common on Gelidium crinale but the number of taxa in the wash usually ranged from one to two and a half times that found on the tips and often equalled that found on the base.

RDA analyses separated the treatments (Fig. 7B) and placed the wash to the left of the two other treatments, more or less intermediary between them. The species associated with the wash in the lower left quadrant (Licmophora abbreviata/gracilis, Achananthes brevipes, and Navicula stompsii) are those that are normally attached to the host plant (true epiphytes) but have been broken off their stipes or come loose from their raphe attachment, especially in January, whereas those in the lower quadrant are more commonly found in the plankton, either true or tychoplanktonic (Thalassiosira spp. and Cymatosira belgica).

\subsubsection{Separation by host plant}

(Fig. 7C, Table 3, Table S2, Fig. S4, S5). When the data were pooled by host, the relative abundance of dominant taxa and their niche breadth $\left(\mathrm{B}_{\mathrm{j}} \mathrm{A}\right)$ can be compared among the hosts. Niche breadth values ranged from 1 , if the taxon was found only on one plant to 3 if equally represented on all three hosts. Although none of the most abundant taxa were found exclusively on only one of the host plants, indicative of obligate host specificity, some were evenly distributed among the host plants and others were distinctly different in abundance among 
Table 3

Comparison of numbers of taxa in each host plant and their diversity and redundancy. For the measurement for the total host, counts for all treatments (wash, tip and base) were pooled for each host and diversity recalculated. Refer to Supplemental Fig. 5 to see community composition parameters for the individual treatments. That marked bold represent the highest values obtained for the study. $\mathrm{R}$ refers to those sampling dates in year two where three replicate samples were taken.

\begin{tabular}{|c|c|c|c|c|}
\hline Date & Replicate & Taxa & $\mathrm{H}^{\prime \prime}$ & REDI \\
\hline \multicolumn{5}{|c|}{ Cladophora dalmaltica or Centroceros clavulaum } \\
\hline Sept 77 GAL & Total Host & 28 & 2.25 & .556 \\
\hline Jan 78 GAL & Total host & 53 & 3.11 & .489 \\
\hline May 78 GAL & Total host & 55 & 3.75 & .377 \\
\hline \multirow[t]{3}{*}{ Sept 78R GAL } & Replicate 1 & 34 & 3.29 & .370 \\
\hline & Replicate 2 & 34 & 3.29 & .320 \\
\hline & Replicate 3 & 19 & 2.56 & .408 \\
\hline \multirow[t]{3}{*}{ Jan 79R GAL } & Replicate 1 & 39 & 3.2 & .417 \\
\hline & Replicate 2 & 45 & 3.53 & .378 \\
\hline & Replicate 3 & 46 & 3.14 & .458 \\
\hline \multirow[t]{3}{*}{ May 79R GAL } & Replicate 1 & 31 & 2.94 & .426 \\
\hline & Replicate 2 & 35 & 2.98 & .441 \\
\hline & Replicate 3 & 27 & 2.71 & .447 \\
\hline Sept 77 PA & Total host & 26 & 2.33 & .525 \\
\hline Jan 78PA & Total host & 49 & 3.15 & .468 \\
\hline May 78PA & Total host & 56 & 4.45 & .250 \\
\hline Sept 78R & Replicate 1 & 46 & 2.81 & .523 \\
\hline \multicolumn{5}{|l|}{ PA } \\
\hline & Replicate 2 & 74 & 4.53 & .299 \\
\hline & Replicate 3 & 59 & 3.38 & .457 \\
\hline \multirow[t]{3}{*}{ Jan 79R PA } & Replicate 1 & 45 & 2.72 & .536 \\
\hline & Replicate 2 & 46 & 2.88 & .509 \\
\hline & Replicate 3 & 50 & 2.83 & .532 \\
\hline \multirow[t]{3}{*}{ May 79R PA } & Replicate 1 & 39 & 2.78 & .502 \\
\hline & Replicate 2 & 24 & 2.55 & .460 \\
\hline & Replicate 3 & 34 & 2.57 & .520 \\
\hline Sept 77 PI & Total host & 39 & 2.79 & .499 \\
\hline Jan 78 PI & Total host & 48 & 2.62 & .567 \\
\hline May 78 PI & Total host & 36 & 2.70 & .502 \\
\hline Sept 78R & Replicate 1 & 52 & 3.41 & .429 \\
\hline \multicolumn{5}{|l|}{ PI } \\
\hline & Replicate 2 & 48 & 2.93 & .508 \\
\hline & Replicate 3 & 40 & 2.68 & .524 \\
\hline \multirow[t]{3}{*}{ Jan 79R PI } & Replicate 1 & 61 & 3.89 & .373 \\
\hline & Replicate 2 & 60 & 3.10 & .512 \\
\hline & Replicate 3 & 59 & 3.60 & .419 \\
\hline \multirow[t]{3}{*}{ May 79R PI } & Replicate 1 & 50 & 2.75 & .550 \\
\hline & Replicate 2 & 50 & 3.22 & .459 \\
\hline & Replicate 3 & 50 & 2.49 & .603 \\
\hline \multicolumn{5}{|c|}{ Gelidium crinale } \\
\hline Sept 77 GAL & Total host & 40 & 3.66 & .329 \\
\hline Jan 78 GAL & Total host & 86 & 4.44 & .338 \\
\hline May 78 GAL & Total host & 49 & 3.84 & .337 \\
\hline Sept 78R & Replicate 1 & 43 & 3.52 & .372 \\
\hline \multicolumn{5}{|l|}{ GAL } \\
\hline & Replicate 2 & 21 & 1.74 & .623 \\
\hline & Replicate 3 & 33 & 2.96 & .434 \\
\hline Jan 79R GAL & Replicate 1 & 50 & 2.96 & .508 \\
\hline & Replicate 2 & 55 & 3.43 & .438 \\
\hline & Replicate 3 & 40 & 2.96 & .470 \\
\hline May 79R & Replicate 1 & 42 & 3.51 & .370 \\
\hline GAL & & & & \\
\hline & Replicate 2 & 53 & 4.24 & .279 \\
\hline & Replicate 3 & 40 & 3.43 & .374 \\
\hline Sept 77 PA & Total host & 57 & 2.58 & .601 \\
\hline Jan 78PA & Total host & 6 & 3.98 & .363 \\
\hline May 78PA & Total host & 57 & 3.30 & .467 \\
\hline Sept 78R & Replicate 1 & 69 & 4.07 & .360 \\
\hline PA & & & & \\
\hline & Replicate 2 & 57 & 3.99 & .340 \\
\hline & Replicate 3 & 54 & 3.97 & .333 \\
\hline Jan 79R PA & Replicate 1 & 7 & 3.22 & .447 \\
\hline & Replicate 2 & 28 & 2.36 & .447 \\
\hline & Replicate 3 & 52 & 2.90 & .527 \\
\hline May 79R PA & Replicate 1 & 48 & 3.53 & .393 \\
\hline & Replicate 2 & 52 & 3.54 & .406 \\
\hline & Replicate 3 & 44 & 2.89 & .500 \\
\hline Sept 77 PI & Total host & 60 & 4.37 & .281 \\
\hline Jan 78 PI & Total host & 43 & 3.37 & .400 \\
\hline
\end{tabular}

Table 3 (Continued)

\begin{tabular}{|c|c|c|c|c|}
\hline Date & Replicate & Taxa & $\mathrm{H}^{\prime \prime}$ & REDI \\
\hline May 78 PI & Total host & 50 & 3.62 & .384 \\
\hline \multirow[t]{3}{*}{ Sept 78R PI } & Replicate 1 & 58 & 3.25 & .479 \\
\hline & Replicate 2 & 47 & 3.23 & .445 \\
\hline & Replicate 3 & 57 & 3.46 & .440 \\
\hline \multirow[t]{3}{*}{ Jan 79R PI } & Replicate 1 & 53 & 2.8 & .548 \\
\hline & Replicate 2 & 72 & 4.12 & .363 \\
\hline & Replicate 3 & 40 & 4.12 & .363 \\
\hline \multirow[t]{3}{*}{ May 79R PI } & Replicate 1 & 79 & 4.46 & .324 \\
\hline & Replicate 2 & 56 & 3.18 & .488 \\
\hline & Replicate 3 & 56 & 3.63 & .404 \\
\hline \multicolumn{5}{|c|}{ Bryocladia cuspidata } \\
\hline Sept 77 GAL & Total Host & 32 & 3.17 & .382 \\
\hline Jan 78 GAL & Total Host & 85 & 4.51 & .332 \\
\hline May 78 GAL & Total Host & 34 & 2.91 & .449 \\
\hline \multirow[t]{3}{*}{ Sept 78R GAL } & Replicate 1 & 41 & 3.82 & .303 \\
\hline & Replicate 2 & 33 & 3.50 & .320 \\
\hline & Replicate 3 & 33 & 3.16 & .392 \\
\hline \multirow[t]{3}{*}{ Jan 79R GAL } & Replicate 1 & 50 & 3.62 & .384 \\
\hline & Replicate 2 & 42 & 2.44 & .580 \\
\hline & Replicate 3 & 42 & 3.17 & .437 \\
\hline \multirow[t]{3}{*}{ May 79R GAL } & Replicate 1 & na & na & na \\
\hline & Replicate 2 & 39 & 3.53 & .351 \\
\hline & Replicate 3 & 40 & 3.33 & .395 \\
\hline Sept 77 PA & Total Host & 66 & 4.22 & .329 \\
\hline Jan 78PA & Total Host & 34 & 2.3 & .576 \\
\hline May 78PA & Total Host & 62 & 4.39 & .282 \\
\hline \multirow{4}{*}{$\begin{array}{l}\text { Sept } 7 \varepsilon \\
\text { PA }\end{array}$} & Replicate 1 & 66 & 4.48 & .281 \\
\hline & & & & \\
\hline & Replicate 2 & 63 & 4.24 & .315 \\
\hline & Replicate 3 & 77 & 4.63 & .287 \\
\hline \multirow[t]{3}{*}{ Jan 79R PA } & Replicate 1 & 52 & 3.88 & .342 \\
\hline & Replicate 2 & 61 & 3.53 & .437 \\
\hline & Replicate 3 & 29 & 1.95 & .626 \\
\hline \multirow[t]{3}{*}{ May 79R PA } & Replicate 1 & 44 & 3.66 & .350 \\
\hline & Replicate 2 & 45 & 3.62 & .362 \\
\hline & Replicate 3 & 53 & 3.58 & .401 \\
\hline Sept 77 PI & Total Host & 65 & 4.19 & .331 \\
\hline Jan 78 PI & Total Host & 48 & 3.28 & .440 \\
\hline May 78 PI & Total Host & 73 & 4.20 & .353 \\
\hline \multirow[t]{3}{*}{ Sept 78R PI } & Replicate 1 & 34 & 2.88 & .465 \\
\hline & Replicate 2 & 70 & 3.98 & .382 \\
\hline & Replicate 3 & 73 & 4.19 & .353 \\
\hline \multirow[t]{3}{*}{ Jan 79R PI } & Replicate 1 & 83 & 4.51 & .323 \\
\hline & Replicate 2 & 56 & 3.86 & .360 \\
\hline & Replicate 3 & 69 & 4.59 & .270 \\
\hline \multirow{4}{*}{$\begin{array}{l}\text { May 79R } \\
\text { PI }\end{array}$} & Replicate 1 & 83 & 4.67 & .295 \\
\hline & & & & \\
\hline & Replicate 2 & 58 & 4.02 & .339 \\
\hline & Replicate 3 & 77 & 4.58 & .296 \\
\hline
\end{tabular}

the host plants. Diversity was calculated for each treatment of the host as well as for the composite count pooled for each host. The diversity was high on each host, ranging from 1.74 to 4.67. A maximum number of 86 taxa were found on Gelidium collected in Galveston in January 1978.

High intertidal hosts (Cladophora in Galveston and Centroceras in Port Aransas and Port Isabel) supported large populations of Achnanthes brevipes v. intermedia, Tabularia tabulata and Licmophora abbreviata. $\left(\mathrm{B}_{\mathrm{j}} \mathrm{A}=2.16,2.57,1.86\right.$, respectively). Navicula stompsii was more abundant on Cladophora than on Centroceras but was also present on the other two mid intertidal plants. Nitzschia frustulum seemed to prefer mid intertidal plants to those in the high intertidal and in the latter habitat seemed to prefer Centroceras to Cladophora but became equally common on all three hosts at Port Isabel.

Bryocladia cuspidata had more epiphytes per unit area than the other hosts (Medlin et al., 1985). Amphora acutiuscula and A. tenerrima were more prevalent on this host, which was most noticeable in Port Isabel. Navicula comoides was more abundant on Bryocladia than the other hosts in Galveston but became numerically important on Gelidium 
and Centroceras in Port Aransas and Port Isabel $\left(\mathrm{B}_{\mathrm{j}} \mathrm{A}=2.55\right)$ and was almost completely absent from Cladophora in Galveston.

The only taxon that was clearly more abundant on Gelidium than on any other host plant was Cocconeis scutellum, although its distribution spread to the other host plants southward $\left(\mathrm{B}_{\mathrm{j}} \mathrm{A}\right.$ is 1.15 at Galveston, 2.12 at Port Aransas, 2.83 at Port Isabel). Other Cocconeis spp. were more abundant at Port Isabel than at the other two sites. Navicula diserta and Rhoicosphenia adolfi were more or less equally distributed among all hosts as was Thalassiosira cf. profunda $\left(\mathrm{B}_{\mathrm{j}} \mathrm{A}=2.83,2.84\right.$ and 2.88 , respectively) but reached its highest proportions in the wash treatment. The other common wash diatom, the small lineate Thalassiosira sp., was not normally abundant in the high intertidal despite being planktonic.

Cymatosira belgica and Grammatophora oceanica had very disjunct populations. C. belgica was reduced in numbers on Cladophora and Centroceras in the upper intertidal and on Geldium in the mid intertidal throughout the sampling period but was abundant on Bryocladia in the wash and base treatments. It was most numerous in Galveston and decreased in abundance on all plants southward. G. oceanica was more or less equally distributed among the host plants in Galveston, more common on Bryocladia in Port Aransas and reduced in numbers on all plants in Port Isabel.

Host plant preferences also seemed to vary by site (Fig. 8). At Galveston and at Port Aransas, Cocconeis scutellum had a clear preference for Gelidium, Licmophora abbreviata for Cladophora/Centroceras at
Galveston. At Port Aransas, Grammatophora oceanica preferred Bryocladia, At Port Isabel, Achnanthes brevipes $v$. intermedia preferred Cladophora/Centroceras and Amphora exigua preferred Bryocladia.

When all treatments are pooled by plant, the evenness of the community can be seen (Table 3). The community on Cladophora and Centroceras tended to be dominated by a few species, whereas that on Bryocladia and Gelidium was more even. The community became dominated by $2-3$ species in the winter.

RDA analyses (Fig. 7C) show that the host plants are distinct from one another but with some overlap. This analysis was first done pooled with the wash and then without the wash, which better separated the host plants. In the latter analysis, the centroids of the three groups were more distant from one another but the amount of scatter within each was the same (data not shown). The species plots associated with the samples plot show Rhoicosphenia adolfi, Cocconeis scutellum and Navicula diserta as having a strong association with Gelidium, Tabularia tabulata, Grammatophora oceanica, and Amphora exigua as strongly associated with Cladophora/Centroceras and Licmophora abbreviata/gracilis, Achnanthes brevipes, and Navicula stompsii more strongly associated with Bryocladia.

Overall, the community on Cladophora was more similar to that on Bryocladia (SIMI $=.750$ ) than to that on Geldium (SIMI $=.222$ ) at Galveston in September (Figs. S4A and B). Moving southward, the community shifted and that on Centroceras was slightly more similar to that on Gelidium (average SIMI $=.879$ ) than to that on Bryocladia
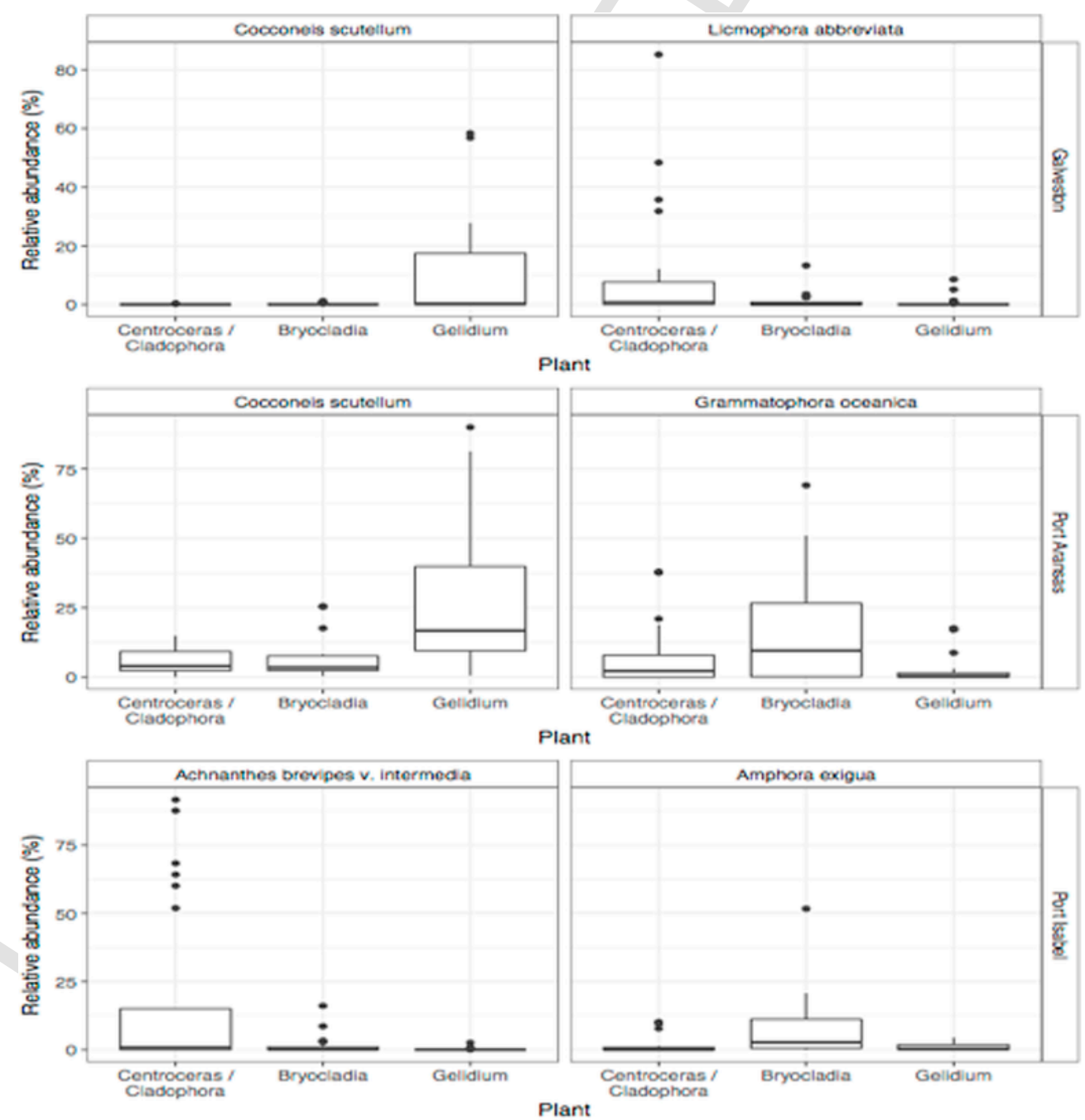

Fig. 8. Box plots showing relative abundance of selected taxa as a function of host plant for each location. 
(SIMI $=.705)$ at Port Isabel. During January, communities on each host plant at each site were comparable (SIMI values ranged from .500 to .978) (with the exception of the very different communities on Bryocladia in January at Port Isabel). In May, the pattern was more variable. The communities associated with Bryocladia and Gelidium responded similarly, when compared to each other, but less dramatically, despite the fact that the similar between the diatom communities was generally higher than that obtained when either host was compared to Cladophora/Centeroceras.

\subsubsection{Separation by season}

Figs. 7D and 9 Table 3, Table S2, Fig. S4). Niche breath values $\left(B_{j} C\right)$ were evaluated for key species for their seasonal distribution. BjC values ranged from 1 if present only in one season to 3 if present in all three seasons. Seasonal differences appeared to be more pronounced in year one than in year two. In the fall, Licmophora spp. were found at all three sites (BjC from 1.17 to 2.78). In Galveston, $L$. abbreviata and $L$. gracilis v. anglica co-occurred. Moving southward, the latter species was gradually replaced by two other taxa: L. jeurgensii and L. cf. hyalina. During the winter, four taxa Rhoicosphenia adolfi, Navicula diserta, Nitzschia frustulum and Grammatophora oceanica account for nearly 50\% of all cells present, but they were also present in all of the other seasons $\left(B_{j} \mathrm{C}=2.3\right.$, $1.59,1.65$, respectively). $R$. adolfi composed from 26 to $31 \%$ of the winter community for both years. Their importance in the community increased southward to Port Isabel. G. oceanica, present in the fall, steadily increased as temperatures dropped. During January, it was the third most abundant taxon, especially at Galveston and Port Aransas. It reached maximum relative abundance during |March, a sampling month that was not counted for the statistical analysis.

During the spring, the metaphyton flourished. Achnanthes brevipes v. intermedia returned after being poorly represented during the winter especially at Port Isabel. Although this species was never significantly abundant, its presence during the spring, predicted a change in the community from that found in the winter. Tabularia fasciculata, commonly found year-round during the first year was more dominant in the spring of the second year, especially at Galveston.

The seasonal change at Port Isabel can lag behind that in Galveston and Port Aransas. During the second year, Grammatophora oceanica

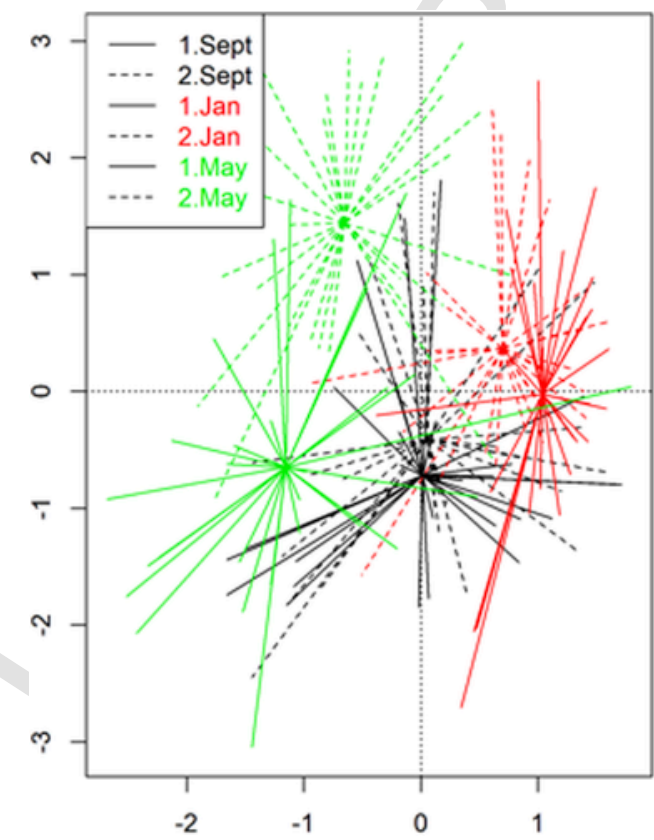

continued to flourish into May mainly at Port Isabel, because its growth was delayed at the most southern station until March of that year (Medlin, 1983).

Cocconeis scutellum, present more or less equally year-round, was most prominent in Port Aransas. In Port Isabel, C. littoralis and C. cf. disrupta competed with $C$. scutellum.

RDA analyses clearly separated the samples by the season in which they were collected (Figs. 7D and 9). Taxa strongly associated with the Sept sampling were Licmophora abrreviata and Navicula diserta, whereas Rhoicsphenia adolfi and Berkelya rutilans were strongly associated with the Jan sampling. The May sampling had more species that were strongly associated with this season: form the wash (Cymatosira belgica, Thalassiosira spp.) and from the attached species (Grammtophora oceanica, Tabularia tabulata, Achnanthes brevipes v. intermedia, Licomphora gracilis v. angelica).

\subsubsection{Niche breadth by interaction of host plant and treatment}

(Table $\mathrm{S} 2$ ) $-\mathrm{B}_{\mathrm{j}} \mathrm{AB}$ values ranged from 1 , with no interaction between the factors to 9 , with strong interaction. Most of the common species averaged between 4 and 6, with only a few species, e.g. Rhoicosphenia adolfi, Navicula diserta and Navicula stompsii showing strong interaction between these factors. The interaction between host plant and treatment was the strongest at Port Isabel.

\subsubsection{Separation by years}

(Fig. 9, Fig. S4, Table 4, Figs. S4A and B). SIMI values compared the similarity of the treatments pooled for each plant pooled across all sites for the two years. Variation in SIMI values reflects changes in the relative abundances of primarily the major taxa, composing $90 \%$ of the total counts. Each season was compared by site for year one and year two. The site of replicate 2 in the second year is the site where all of the host plants were collected in year 1 .

There was a distinct seasonal change in the diatom flora, which was more pronounced the first year. SIMI values, comparing treatments for each year, are presented in Figs. S4A and B. Washes were more different from that attached to the host plants in the warmer months. In January, the washes on Bryocladia were very similar to those attached to the plant, but this is mainly a reflection of attached plants coming off

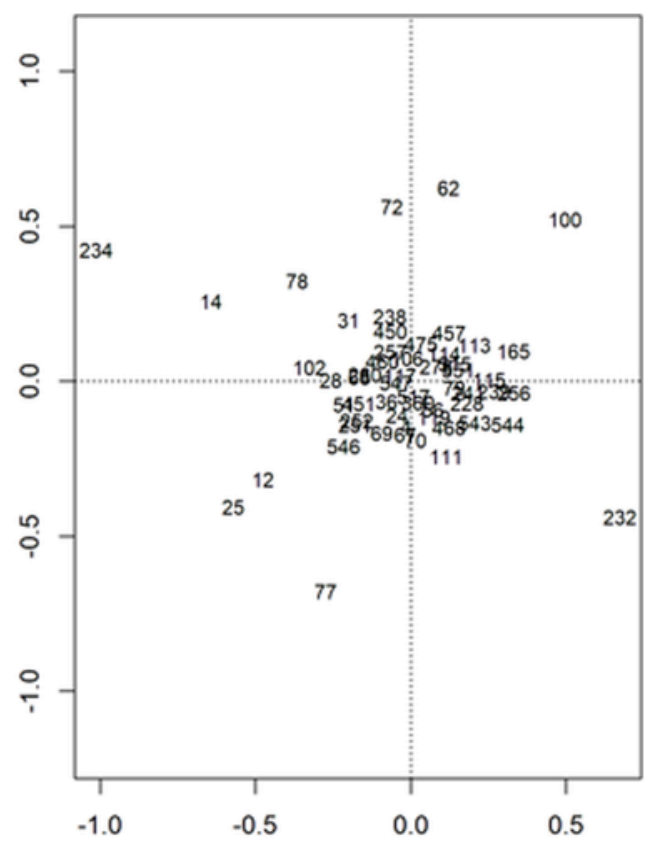

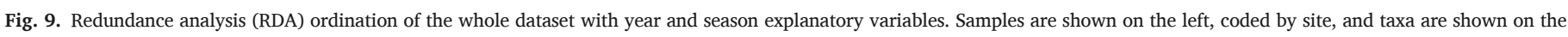
right. See Table S2 for taxon codes/names. 
Table 4

Similarity (SIMI) comparisons (A) by sites (pooled for all of the taxa for the two sampling years and (B) by seasons (September, January, May) for the two years. G= Galveston, PA $=$ Port Aransas PI = Port Isabel.

A)

\begin{tabular}{lll}
\hline & G & PA \\
\hline PA & .870 & \\
PI. & 843 & .914 \\
\hline
\end{tabular}

(B)

\begin{tabular}{llllll}
\hline Year 1 & \multicolumn{5}{c}{ Year 2 } \\
\hline & $\mathrm{S}$ & $\mathrm{J}$ & $\mathrm{J}$ & $\mathrm{S}$ & $\mathrm{J}$ \\
$\mathrm{J}$ & .899 & & $\mathrm{~J}$ & .934 & \\
$\mathrm{M}$ & .887 & .744 & $\mathrm{M}$ & .841 & .890 \\
\hline
\end{tabular}

the host plant. During the first year at Galveston, the species assemblages washing off the hosts were significantly different from those attached to Bryocladia and Gelidium in September and May, whereas that washing off Cladophora more closely resembles the attached assemblages. One reason for this similarity was the ease with which Licmophora cells were broken off their stipes when hosts were manually agitated, thus biasing the assemblage washing off Cladophora/Centroceras. Gelidium exhibited the most differences between the metaphytic and epiphytic communities. When the data were pooled by year, the diatom community sampled over the two year periods was $95 \%$ similar. The assemblages washing off Centroceras during the winter of both years was not comparable to that found attached to the host plant itself. Washes and host plant assemblages were most alike in January. The only plant to exhibit a distinct zonation pattern of the attached flora was Bryocladia during May and this was documented by SEM (Medlin et al., 1985). This pattern was repeated the second year at Galveston, and at Port Aransas for both years, although not as distinctly. Differences between tips and bases of the hosts were not found except on Gelidium in the spring of the second year and on Cladophora in the spring of the first year.

The species assemblages within the hosts at Port Isabel were very dissimilar for both years (Figure S4A,B). During the first year, washes were not comparable to that from the host plant for Gelidium and Bryocladia in May. During January all portions of Geldium were unrelated to one another. Cladophora exhibited a distinct zonation pattern in May. The wash was very similar to the tips again because Licmophora cells were broken loose from their stipes. The species assemblage within each host was remarkably similar during the second year. That washing off Centroceras in the fall and off Cladophora in the spring displayed the most dissimilarity to the other portions of the plant.

The Duncan's multiple range test of the means of the SIMI indices showed that the host plants collected in September were statistically different from those collected in May. This reflects the difference in the similarity of the diatom communities from September to May with January being a month when the diatoms assemblages on all host plants were most alike. SIMI values for pooling all data and comparing by site showed a clear geographic difference. Port Aransas and Port Isabel were the most similar, with Galveston being more closely related to Port Aransas than to Port Isabel (Table 4).

RDA analyses showed that the Sept and January samples for the two years were rather similar, whereas the May samples were distinctly different and more distantly placed on the ordination plot (Fig. 9). If the salinity values are examined by season, it can be seen that in year two, salinity was more variable (Fig. S1) and very different from that in year one and likely this accounts for the separation of the database by season, which, taken with salinity $(14 \%+16 \%$, respectively), explains almost one third of the variation in the diatom community.

\subsection{Statistical support of the epiphyte community}

RDA analyses could assess the \% variation in each of the above analyses (Table 5). At all three sites, season explained $14 \%+$ of the variation, followed by the host plant at $8-9 \%$. Treatment explained $6 \%$ of the variation at Galveston, $13 \%$ at Port Aransas and 9\% at Port Isabel. Shared effects between pairs of factors generally explained less than $1 \%$ of the variation in each case, suggesting that each factor tested had a strong and independent influence on the variation recovered.

\section{Discussion}

The diatom flora associated with the host plants selected from the Texas coast is a diverse and abundant assemblage that is typical of open coast areas rather than estuarine waters (Stowe, 1982; Sullivan, 1980) and similar to that found on floating Sargassum spp. (Maples, 1984), but different from the epiphytic community found on mangroves in Louisiana (Maples, 1983), in India (Bhat \& Sivakumar 2013) and in Brazil (Corrêa da Rosa and Garcia, 2015), where more motile taxa were found and in general the community had more freshwater taxa. This study shares only about $20 \%$ of the taxa found in the epiphyte study from rhodophyte macroalgae from Veracruz, Mexico (Siqueiros Beltrones and Martínez, 2017).

Qualitative examination of a wide variety of host plants from three major macroalgal classes showed that not all plants were equally used as host substrates. Medlin (1983) provided a detailed analysis of which macroalgae hosted a varied epiphyte population and which did not. Rhodophytes provided better host substrates than phaeophytes, then chlorophytes in terms of relative abundances. This may reflect the subtropical habitat of the study sties and the relative abundance of these macroalgal groups in the study area. Similar results were found for the epiphytic flora on Antarctic macroalgae where rhodophytes were better substrates than phaeophytes (Majewska et al., 2016) and for macroalgae in the Baltic (Snoeijs, 1994). In Iceland, two orders of magnitude in variation were found in replicates of the same host plant, whereas the replicates here were over 95\% similar to each other, with only a few exceptions (Medlin, 1983). Blindow (1987) found no differences in the epiphytic diatom community with respect to site, host plant or host plant part. However, her replicates were more similar to one another than to other plant samples, suggesting some kind of subtle differences among the host plants that could not be identified by multivariate analyses.

Abiotic factors: The host plants sampled here occurred in two intertidal locations: high and mid intertidal. Most studies on epiphytic diatoms have taken samples over an intertidal range (see Medlin, 1983). The tidal range in the Gulf of Mexico is usually $<1 \mathrm{~m}$ and within this tidal range, the high intertidal is separated from the mid intertidal by

\section{Table 5}

Results of variance partitioning, showing the relative proportion of variance in diatom assemblages accounted for by season, host type and treatment at each location. Those values in grey represent the variance partitioning excluding any variance that can be attributed to interaction of the factors.

\begin{tabular}{|c|c|c|c|}
\hline & Galveston & $\begin{array}{l}\text { Port } \\
\text { Aransas }\end{array}$ & $\begin{array}{l}\text { Port } \\
\text { Isabel }\end{array}$ \\
\hline Season & 14 & 14.5 & 14 \\
\hline Plant & 8 & 8 & 9 \\
\hline Treatment & 5.8 & 13 & 9.8 \\
\hline Season & 13 & 14 & 13 \\
\hline Plant & 6.3 & 6.8 & 8.1 \\
\hline Treatment & 4.1 & 12.1 & 8.5 \\
\hline
\end{tabular}


about $20 \mathrm{~cm}$. Despite this small distance, some zonation patterns were recovered. Light-loving species, such as Achnanthes and Licmophora, were consistently abundant on the tips of the high intertidal Cladophora and Centroceras. In the mid intertidal, these taxa were more numerous on the branchlets rather than the main axis of Bryocladia, (Medlin et al., 1985). They did not flourish on Gelidium. Their abundance in the spring through summer in this study was also found in other epiphytic diatom studies where seasonal studies were performed (Simonsen, 1962; Castenholz, 1964; Hopkins, 1964; Main and McIntire, 1974; Stevensen and Stoermer, 1982; Jacobs and Noten, 1980; Snoeijs, 1994; Majewska et al., 2016).

In more temperate areas, Navicula comoides and Grammatophora oceanica are more restricted to lower intertidal or subtidal areas (Edsbagge, 1966; Simonsen, 1962). Here, these species exhibited different adaptations to the environment. G. oceanica, although present year-round, reached its maximum abundance during the winter, a time when light intensities were at their lowest. This response is similar to that of Grammatophora spp. in the Ouse Estuary UK (Hopkins, 1964). $N$. comoides is more restricted to the host base, especially on those of the mid intertidal zone, where it would be shaded by the upper most branches of the host plant.

In the Antarctic epiphytic study (Majewska et al., 2016), sampling depth accounted for $10 \%$ of the variation, with tube dwelling diatoms being at the shallowest depths and stipate (erect) and metaphytic forms were found in the deepest samples. True planktonic species were also recorded but exhibited no preference to depth. Motile diatoms were found at all depths and on all host plants with some hosts more covered than others (Majewska et al., 2016).

Sediment associated diatom communities rarely exhibit any seasonal variation (McIntire and Moore, 1977; Whiting, 1983), whereas epiphytic and epilithic assemblages usually have more distinct seasonal changes (Snoeijs, 1994; Majewska et al., 2016). Here, seasonal changes in the epiphytic flora were subtle. Dominant taxa were usually present year-round, with relative abundances changing seasonally. Nevertheless, these differences were statistically significant and accounted for up to $14 \%$ of the variation.

During the spring, there were usually about ten taxa that co-dominated the community. The plankton members of the metaphyton were numerically important then. As the season changed, the number of numerically dominant taxa steadily decreased. Achnanthes brevipes v. intermedia reached maximum abundance during the warmest part of the year, whereas Licmophora spp. did during the late summer and early fall. By winter three taxa, Rhoicosphenia adolfi, Navicula diserta, and Grammatophora oceanica, were the dominant taxa.

These seasonal changes are not drastically different from those of more temperate areas. Many taxa are shared, although some, such as Rhoicosphenia abbreviata (= curvata) are replaced by more tropical forms ( $R$. adolfi). $R$. abbreviata is commonly cited as one of the most numerous members of the epiphytic community in more temperate studies where it is present year-round but reaches maximum development in the winter (Main and McIntire, 1974; Rautianinen and Ravanko, 1974; Taasen, 1974; Ronnberg and Lax, 1980; Stevensen and Stoermer, 1982; Whiting, 1983; Snoeijs, 1994). $R$. adolfi follows the same pattern along the Texas coast.

In temperate areas, Cocconeis scutellum co-occurs with $C$. placentula and $C$. pediculus. C. scutellum is numerically important along the Texas coast but its importance decreases southward as it competes with more tropical taxa, such as C. woodii, C. littoralis, and C. cf. disrupta. Cocconeis spp. dominated epiphytic samples from submerged spermatophytes in Turkish Lakes (Yüce and Gönülol, 2016). C. scutellum was found to be the most abundant diatom in the epiphytic community in Iceland (Totti et al., 2009).

During the winter, the diatoms communities associated with each host plant were more alike. As host plant growth decreases, so would the production of any inhibitory compounds that might be preferentially affecting the diatom community as well as nutrient availability to the epiphytes. Greater variation among the host plant communities occurred during May and September when hosts were actively growing. Replicate host plants supported markedly similar diatom assemblages, (except for those collected at Galveston during September 1978), which would indicate that possibly biological interaction between host plant and the epiphyton played a greater role than interaction with the environment. Changes were correlated with salinity and not with temperature except on a seasonal basis. Other studies have also shown that season plays a strong role in the structuring of the epiphytic community. Majewska et al. (2016) suggested that seasonal effects were stronger than natural variability, especially after ice breakup. Snoeijs (1994) found that season was recovered in the first axis of her canonical correlation. In Brazil, the season controlled the type of epiphytic community that dominated: spring (motile), summer (chain), autumn (tube forming) winter (tube forming and motile) (Corrêa da Rosa and Gracia, 2015).

RDA analyses showed that season, host plant and treatment all played an important part in structuring the epiphytic community. This completely contrasts with the variation among vs. between host plants reported by Main and McIntire (1974). That study was in an estuary where adaptation to physio-chemical stresses are of primary importance in the life strategies of organisms that live there. Thus, within host variations of the epiphytic diatom communities could easily exceed that between hosts, because biological interaction is downplayed.

That there was such a gradual change in the diatom community from Galveston southward to Port Isabel was surprising especially because Hendey (1951) found a large difference in epiphyte species composition between collection sites along a relatively short length of coastline in northern Cornwall, UK. The water quality along the Texas coast of the Gulf of Mexico improves from Galveston to Port Isabel as evidence by the sediment load into the basins, as well as by the reduction in the amount of shipping traffic southward. The Galveston jetties mark the entrance to the Houston Ship Channel where oil spills and other pollutants can be locally heavy. The growing season increased gradually from Galveston to Port Isabel and undoubtedly affects the diversity of the epiphytic diatom community structure as it surely does the macroalgal community. Thus, the improved water quality, the lengthened growing season, the decreased salinity range southward to Port Isabel, and the improved water quality may all be involved in the gradual change in the epiphytic diatom community southward from Galveston to Port Isabel. Multivariate analysis identified salinity as explaining $16 \%$ of the variation in the continuum from Galveston to Port Isabel. The differences in the salinity regime in year 2 as compared to year 1 (Fig. S2) is most likely the cause of the shift in the May samples for the two years. In year 2 , the salinity was much lower leading into the summer of that year (Fig. S2). Moving even further southward to Veracruz, Mexico, only 27 taxa from the 155 taxa identified by Siqueiros Beltrones and Martínez (2017) were shared by this study and only one of the Mastogloia spp.

Other studies on epiphytes have also showed that the community responded to selected abiotic factors. Snoeijs (1994) found salinity to be correlated with the second axis in her canonical correlation studies in the Baltic. Nutrients increased or decreased with salinity and thus showed the same but minor influence on the epiphytic diatom community.

From a worldwide biogeographical point of view, many epiphytic diatoms have a cosmopolitan distribution, although the Arctic taxa certainly disappear from the epiphytic communities as one more towards warmer climates. Also the number of species in certain genera changes from temperate to tropical areas (compare only 1 Mastogloia spp. in Hendey (1951) and 1 in Snoeijs (1994) from cold termperate waters to 12 found in this study and $>30$ in studies from the South Pacific 
(Ricard, 1974) but only 4 found in Veracruz, Mexico (Siqueiros Beltrones and Martínez, 2017). Some genera (e.g. Climacosphenia) are restricted to distinct warmer temperature regimes. Thus, differences in the abundance of taxa in local study areas may reflect more subtle reaction to their habitat. Many of the same species found in Snoeijs (1994) were also found in this study but were not found in the study by Sullivan $(1977,1980)$ in Mississippi because he examined seagrasses rather than macroalgae. There is also a high percentage of Mastogloia spp on seagrasses in the Gulf of Mexico (Frankovich et al., 2006) but not so many on macroalgae (this study and Siqueiros Beltrones and Martínez, 2017).

\subsection{Host plant}

The effect of thallus shape on the colonisation sequence of the epiphytes was shown in Medlin et al. (1985). RDA analyses have documented that the diatom communities on the three hosts were significantly different and contributed up to $8 \%$ of the community variation. Host plant projections induce cell settlement and the absence of projections on Gelidium, which break up the fluid dynamics around the host, may also be the cause of its reduced epiphytic community. In contrast to the colonisation sequence on glass slides (Hoagland et al., 1982) where high profile diatoms are the last to settle, these diatoms were the first to settle, being found at plant tips rather than the base. Either this is a requirement for higher light or a response to anti-biogenic compounds produced by the host plant. Extracts from host plants have significantly influenced diatom growth (Lam et al., 2008) and experiments could be performed from these host plants to determine what, if any, anti-biogenic compounds were being secreted to modify the epiphytic community. Rhoicosphenia adolfi produced long stipes when attached to the tips of the plant and no stipe at the base of the plant (Medlin et al., 1985, Figs. 3B and 5D). Low lying forms were primarily at the base of the plants or on main axes and were always covered with copious amounts of mucilage, which may be a protective coating because they are in close contact the plant surface. Sloughing of the cell wall of $B$. atropurpurea prevents a lower density of epiphytes (Lowe et al., 1982). Snoeijs (1994) found that the diameter of the host plant influenced the type of diatom settling on it. Mutinová (2015) tested eight different host plant shapes and found no significant differences in the associated communities. In their review of epiphytes in freshwater systems, Letákovááa et al. (2018) noted that the host plant had a profound effect on the community structure, not only in terms of biological affects but also physical and chemical ones, noting positive, negative and neutral effects in most categories. They also felt that the evidence for host specificity was inconclusive and required more investigation.

It is not surprising that, living within the branches of the macroalgae, there is a very diverse community that is not securely attached to the host plant substrate. Intense wave action easily stirs up the silty sediments of the Gulf coast and cells, both plankton and benthic, settle within the branches. Small centrics, e.g., Thalassiosira, Cyclotella and Minidiscus, were commonly washed form the host plants. Other centrics, e.g., Thalassiosira decipiens, Biddulphia biddulphiana, Odontella aurita and Podosira montagnei, are true epiphytes. Epipelic taxa were also present in the metaphyton but never abundant. Exception to this were $C y$ matosira belgica, Plagiogrammopsis vanheurckii, Pleurosigma spp. and Gyrosigma spp., once trapped within the mucilaginous waters surrounding the host plants these representatives of the plankton and epipelon can continue to thrive as evidence by this and other studies (Main and McIntire, 1974; Snoeijs, 1995).

Much of the epiphytic diversity was associated with the wash from the plant, especially for Cladophora/Centroceras and Gelidium, the former being in the high intertidal and receiving the maximum of the wave inundation. RDA methods showed that treatment differences were highly significant. Other studies have identified diatoms that were not attached to the host (Snoeijs, 1994; Totti et al., 2009) but none of these studies physically washed the plants to separate the metaphytic community from the true epiphytic one. Snoeijs (1994) divided her metaphyton taxa into two groups: tube dwelling forms and motile forms. In this study, tube dwelling forms were found to be attached to the host plant and were not found in the washes.

Direct observations and SEM observations documented that the density of the epiphytic colonisation per unit area was not uniform across the host plants studies (Medlin et al., 1985). This was especially true for Geldium and Bryocladia, which occurred side by side in the intertidal zone and thus, environmental variables that could influence the diatom community were minimized between the host plants on a relative scale. Thus, the host plant, whether by biochemical or structural means was directly involved in shaping the associated epiphytic community and the question of host specificity or at least the intensity of epiphytes on different host plants bears further investigation.

Gelidium was shown to host the most distinctive diatom community and this is likely reflected by its flat shape and lack of branchlets to induce the epiphyte settlement. The notable decrease in diatom colonisation per unit area on Gelidium could also be related to host plant inhibitory compounds being secreted. Most of the diversity of the diatom community associated with Gelidium was in the metaphyton. Often monospecific areas of Cocconeis were found (Medlin, 1983). Ramm (1977) has suggested that perhaps these flat embedded taxa need a wider surface area for attachment. This would help explain the almost monospecific stands of Cocconeis reported from cartilaginous hosts (Majewska et al., 2016) and from seagrasses (Sullivan, 1977), but such a physical explanation cannot account for colonisation of Cocconeis spp. on Chaetomorpha or of Rhopalodia on Ectocarpus (Medlin, 1983). In the Baltic study (Snoeijs, 1994) Cocconeis exhibited the strongest host preference. They did not occur on the brown alga Pilayella, which was too narrow to allow the cell to adhere to its surface, whereas Ceramium had larger areas of a flattened thallus where it was abundant.

Plocamium was the preferred host among the three red host plants studied by Majewska et al. (2016) with more branches than the others sampled and supported the most diverse flora. Totti et al. (2009) studied a variety of host plant shapes and found that the diatom community responded to the host plant shape. But they found that erect species were commonly on flat thalli, whereas in this study, adnate species were dominant on Gelidium, which represented the most flattened host plant shape in this study. Snoeijs (1994) found that the host preference was mainly one of abundance with the most abundant diatom community being found on the red host Ceramium, which had the smallest surface area. This was reversed in the autumn when Cladophora had the most abundant coverage. This was at a time when the host plant was dying and she concluded that the release of nutrients encouraged the settlement and proliferation of the diatom community.

\subsection{Zonation on the host plant}

Each host plants displayed distinct colonisation and succession sequence and showed evidence of host related differences in these patterns as expressed by differences in their abundances (Costa et al., 2014). A vertical zonation of epibonts was evident on each host plant (Medlin et al., 1985), which was most dramatic within a few millimetres of the tips as documented with SEM (Medlin et al., 1985). Tips were shown to be statistically different from the bases at certain times of the year. Fouling occurred sporadically near the extreme tips and was in most cases, initiated by bacteria and later replaced by diatoms, which is a common settling sequence on glass slides (Hoagland et al., 1982). On high intertidal host, Centroceras, species diversity and relative abundance of the epiphytes increase distally from the tip as the epiphytes settled first within the nodes and behind the spine and later 
on the surface of the corticating cells (Medlin et al., 1985 Fig. 4). Changes in attachment mechanisms from the tip to the base of the plant may indicate biological interactions.

On Bryocladia, species diversity and relative abundance of the epiphyton increased similarly. At the plant base, diatoms species requiring high light intensity, such as Licmophora and Achnanthes, no longer occurred. These species are attached by long stipes near the apex and primarily on the branchlets. This stipes may serve to lift the diatom above the macroalgal surface in response to alleopathic compounds as well as to lift the cells above the shadowing effects of the branchlets. Cocconeis spp. and Amphora spp. occurred in high numbers on the main axis than on the branchlets where they may be out-competed for available space and nutrients and may be somewhat light inhibited. Amphora spp. are coated with mucilage and Cocconeis spp. are actually embedded in the host epidermal tissue. These attachment mechanisms could be interpreted as either responses to inhibitory compounds or to abiotic factors. Podosira montagnei and Biddulphia biddulphiana were always found heavily coasted with mucilage and consistently found at the plant base because they are likely inhibited by high light intensities or perhaps antibiotic compounds.

The strength of the cells' attachment mechanisms may be species-specific. Taxa belonging to the metaphyton would be expected to be greater in wash, whereas the true epiphytes would be more concentrated on the plant surfaces. Navicula stompsii, a tube dwelling species, was commonly washed from the plant, perhaps because the tubes were intermingled within the branches of the host plant, but $N$. comoides was not. Navicula diserta, which was attached by its apex to the plant surface, was also easily removed from the host plant. The tensile strength of the short mucilage stipe of Rhoicosphenia adolfi enabled it to be more securely fattened to the host plant, thus attributing to its lower numbers in the wash. Mucilage pads attaching Grammatophora oceanica and Tabularia tabulata and the short mucilage stipe of Achnanthes brevipes v. intermedia were fairly effective attachment means. However, by comparison, Licmophora abbreviata was more numerous in the wash than on the plants because the cells were easily broken loose from their longer stipe. During this study, dead or empty cells of Licmophora were never found attached to their stipe. Of those species attached directly to the host surface by the raphe (Cocconeis scutellum, Amphora acutiuscula, Amphora tenerrima), fewer cells of C. scutellum were found in the wash than the other two taxa. These were mostly rapheless valve because host epidermal tissue grows around the raphe valve, which is still attached. Empty raphe valves remain attached to the host long after the cell has dies; the rapheless valve is sloughed. Cattaneo and Kalff (1978) found more loosely attached epiphyton (phytoplankton) on host plants and their plastic replicas primarily early in the growing season when the phytoplankton was abundant. This metaphyton was more diverse and had more biomass than the true epiphytic community as was shown in this study.

\section{Conclusions}

This study represents the first investigation of epiphytic diatoms from the Texas coast as well as the first seasonal study of epiphytes over a two year period in North America as far as we are aware. The epiphytic diatom community along the coast is spatially and temporally dynamic. Both metaphyton and epiphyton were identified and statistically different. There is a gradual change in the community composition along the 250 mile Texas coast of the Gulf of Mexico strongly correlated with salinity. Epiphyte colonisation sequences respond to macroalgal hosts in both biological and physical factors. Some species were more prevalent on the tips rather than the host bases and in the wash. Certain species were strongly associated with certain hosts, suggesting host specificity. There was also a dramatic difference in epiphytic coverage per unit area for different host plants with different shapes and different intertidal locations associated with exposure Such responses generate new hypotheses for understanding attachment mechanisms and possible control of fouling organisms in the marine environment.

\section{Acknowledgements}

These samples represent the unpublished doctoral work of L. K. Medlin. The community composition statistics at that time along with the reciprocal averaging multivariate analysis were performed under the auspices of Dr. C.D. McIntire, Oregon State University were limited by computer capacity. All treatment data had to be pooled per plant, masking the effects of host specificity and zonation. These data were reanalysed here as separate partitions using modern RDA analyses to show the effects of treatment and the results from the reciprocal averaging multivariate analysis, giving a broader environmental perspective.

\section{Appendix A. Supplementary data}

Supplementary data related to this article can be found at https:// doi.org/10.1016/j.ecss.2018.06.011.

\section{Uncited references}

Colijn, 1978; Hillebrand et al., 2000; Millie and Lowe, 1983; Penhale and Smith, 1977; Sieburth, 1975; Siver, 1978.

\section{References All of the scientific names have lost their italics in the references}

Aleem, A.A., 1949. Distribution and ecology of marine littoral diatoms. Bot. Mar. 4, $414-440$.

Aleem, A.A., 1950. Distribution and ecology of British littoral diatoms. J. Ecol. 38, 75-106. Aleem, A.A., 1969. Zonal distribution of littoral diatoms at Cullercoats, Northumberland (England) and their relation to the plankton. Pubbl. Sta. Zool. Napoli. 37, 332-368.

Baardseth, E., Taasen, J., 1973. Navicula dumontiae sp. nov. an endophytic diatoms inhabiting the mucilage of Dumontia incrassata (Rhodophyceae). Norweg. J. Bot. 20, $79-87$

Barbosa, M., Valentão, P., Andrade, P.B., 2014. Bioactive compounds from macroalgae in the new millennium: implications for neurodegenerative diseases. Mar. Drugs 12, 4934-4972.

Behre, K., 1943. Die Algenbesiedlung einiger seen um Bremen und Bremerhaven. Ver. Inst. Meeres. Forsch. Bremerh. 4, 221-383.

Bhat, O.A., Sivakumar, K., 2013. Light and scanning electron microscopic studies of epiphytic diatoms associated with mangroves. Int. J. Sci. Res. 4, 2011-2017.

Blindow, I., 1987. The composition and density of epiphyton on several species of submerged macrophytes - the neutral substrate hypothesis tested. Aquat. Bot. 29, 157-168.

Borcard, D., Gillet, F., Legendre, P., 2011. Numerical Ecology with R. Springer, Dordrecht.

Callow, M.E., Evans, L.V., 1981. Some effects of triphenyltin chloride on Achnanthes subsessilis. Bot. Mar. 24, 201-205.

Castenholz, R.W., 1961. The effect of grazing on marine littoral diatom populations. Ecol. 38, 75-106.

Castenholz, R.W., 1964. The effect of daylight and light intensity on the growth of littoral marine diatoms in culture. Physiol. Plantarum 17, 951-963.

Cattaneo, A., 1978. The microdistribution of epiphytes on the leaves of natural and artificial macrophytes. Br. Phycol. J. 13, 183-188.

Cattaneo, A., Kalff, J., 1978. Seasonal changes in the epiphyte community of natural and artificial macrophytes in Lake Memphremagog (Que. \& Vt.). Hydrobiologia 60, $135-144$.

Cattaneo, A., Kalff, J., 1986. The effect of grazer size removal on periphytic communities. Oecologia (Berl.) 69, 612-617.

Colijn, F., 1978. Primary Productivity Measurements in the Ems-dollard Estuary during 1975 and 1976 (Publications and reports of the project 'Biological Research in the Ems-Dollard estuary).

Conover, J.T., Sieburth, J.M., 1963. Effect of Sargassum distribution on its epibiota and antibacterial activity. Bot. Mar. 6, 147-157.

Corrêa da Rosa, V., Garcia, M., 2015. Ecological guilds of epiphytic diatoms (Bacillariophyta) on Acrostichum danaeifolium Längst. \& Fisch in a subtropical wetland in southern Brazil. Acta Limnol. Bras. 27, 311-321.

Costa, M., Pereira, S., De Arruda, P., Eskinazi, L.E., 2014. Quantitative variation of epiphytic diatoms in Galaxaura rugosa (Nemaliales: rhodophyta). Mar. Biodiv. Rec. 7 E85. https://doi.org/10.1017/S1755267214000529.

Dabek, P., Witkowski, A., Bornman, T.G., Gorecka, W., 2015. Marine epiphytic diatom assemblages from the Atlantic coast of South Africa. In: Poster 8.PO.11 6th European Phycological Society Meeting, London. 
Daniel, G.F., Chamberlain, A.H.L., Jones, E.B.G., 1980. Ultrastructural observations on the marine fouling diatom Amphora. Helgol. Meeresunters. 34, 123-149.

Edsbagge, H., 1966. Zur Ökologies der marinene angehefteten Diatomeen. Alquist and Wiksel, Stockholm, 154, Bot. Goth. vol. I.

Edwards, P., 1970. Illustrated guide to the seaweeds and seagrasses in the vicinity of Port Aransas, Texas. Contrib. Mar. Sci. 15, 1-128.

Eminson, D., Moss, B., 1980. The composition and ecology of periphyton in freshwaters. Br. Phycol. J. 15, 429-446.

Evans, L.V., 1981. Marine algae and fouling: a review, with particular reference to ship fouling. Bot. Mar. 24, 167-171.

Fitzgerald, G.P., 1969. Some factors in the competition of antagonism among bacteria, algae and aqautic weeds. J. Phycol. 5, 351-359.

Frankovich, T.A., Gaiser, E.E., Zieman, J.C., Wachnicka, A.H., 2006. Spatial and temporal distributions of epiphytic diatoms growing on Thalassia testudinum Banks ex König: relationships to water quality. Hydrobiol. (Sofia) 569, 259-271.

Frankovich, T.A., Armitage, A., Wachnicka, A.H., Gaiser, E.E., Fourqurean, 2009. Nutrient effects on seagrass epiphyte community structure in Florida Bay. J. Phycol. 45, 1010-1020.

Gauch, H.G., Whitaker, R.H., Wentworth, T.R., 1977. A comparative study of reciprocal averaging and other ordination techniques. J. Ecol. 65, 157-174.

Godward, M.B., 1934. An investigation of the causal distribution of algal epiphytes. Bot. Central Ges. Bot. Heih. 52, 506-539.

Harper, J.T., Garbary, D.J., 1994. Host specificity of Podocystis adriatica on the red alga Heterosiphonia crispella from Senegal. Diatom Res. 9, 329-333.

Hendey, N.I., 1951. Diatoms of Chichester Harbour with special reference to fouling. J. Roy. Microsc. Soc. 71, 1-86.

Hillebrand, H., Worm, B., Lotze, H.K., 2000. Marine microbenthic community structure regulated by nitrogen loading and grazing pressure. Mar. Ecol. Prog. Ser. 204, 27-38.

Hoagland, K.D., Roemer, S.C., Rosowski, J.R., 1982. Colonization and community structure of two periphytic assemblages with emphasis on the diatoms. Am. J. Bot. 69, 198-213.

Holt, G., 1980. Fastsittende diatomeeer pa gronnalger i Norge og pa Faroyene. Blyttis 39, 9-17.

Hopkins, J.T., 1964. A study of the diatoms of the Ouse Estuary, Sussex. III. The seasonal variation in the littoral epiphyte flora and the shore plankton. J. Mar. Biol. Assn. UK 44, 613-644.

Hornsey, I.S., Hide, D., 1974. The production of antimicrobial compounds by British marine algae. I. Antimicrobial producing marine algae. Br. Phycol. J. 9, 353-361.

Hornsey, I.S., Hide, D., 1976a. The production of antimicrobial compounds by British marine algae. II. Seasonal variation in production of antibodies. Br. Phycol. J. 11, 63-67.

Hornsey, I.S., Hide, D., 1976b. The production of antimicrobial compounds by British marine algae. III. Distribution of antimicrobial activity within the algal thallus. Br. Phycol. J. 11, 175-181.

Jacobs, R.D.W.N., Noten, T.M.P.A., 1980. The annual pattern of the diatoms in the epiphyton of eelgrass (Zostera marina L.) at Roscoff, France. Aquat. Bot. 8, 355-370.

Lam, C., Grage, A., Schulz, D., Schulte, A., Harder, T., 2008. Extracts of North Sea macroalgae reveal specific activity patterns against attachment and proliferation of benthic diatoms: a laboratory study. Biofouling 24, 59-66.

Le Bail, A., Billoud, B., Kowalczyk, N., Kowalczyk, M., Gicquel, M., Le Panse, S., Stewart, S., Scornet, D., Cockd, J.M., Ljung, K., Charrier, B., 2010. Auxin metabolism and function in the multicellular brown alga Ectocarpus siliculosus. Plant Physiol 153, $128-144$.

Lee, M.J., Ellis, R., Lee, J.J., 1982. A comparative study of photoadaptation in four diatoms isolated as endosymbionts from larger foraminifera. Mar. Biol. 68, 193-197.

Legendre, P., Gallagher, E., 2001. Ecologically meaningful transformations for ordination of species data. Oecologia 129, 271-280.

Letákovááa, M., Fránková, M., Poulíčková, A., 2018. Ecology and application of freshwater epiphytic diatoms - review. Cryptogam. Algol. 39, 3-22

Lowe, R.L., Rosen, B.H., Kingston, J.C., 1982. A comparison of epiphytes on Bangia atropurpurea (Rhodophyta) and Cladophora glomerata (Chlorophyta) from northern Lake Michigan. J. Great Lake. Res. 8, 164-168.

Lubchenco, J., 1978. Plant species diversity in a marine littoral community: importance of herbivore food preferences and algal competitive abilities. Am. Nat. 112, 23-39.

MacArthur, R.M., 1965. Patterns of species diversity. Biol. Rev. 40, 510-533.

Main, S.P., McIntire, C.D., 1974. The distribution of epiphytic diatoms in Yaquina Estuary, Oregon (USA). Bot. Mar. 17, 88-99.

Majewska, R., Convey, P., De Stefano, M., 2016. Summer epiphytic diatoms from terra nova bay and cape Evans (ross sea, Antarctica) - a synthesis and final conclusions. PLoS One 11 (4)https://doi.org/10.1371/journal.pone.0153254.

Maples, R.S., 1983. Con y structure of diatoms epiphytic on pneumatophores of the black mangrove, A 20 ia germinans, in a Louisiana Salt Marsh. Gulf Res. Rep. 7, 255-259.

Maples, R.S., 1984. The epiphytic diatom flora of two Sarga pecies. Gulf Res. Rep. 7, 373-375.

Marks, J.C., Power, M.E., 2001. Nutrien changes in the species composition of epiphytes on Cladophora glomerat (Chlorophyta). Hydrobiol. (Sofia) 450, 187-196.

McIntire, C.D., Moore, W.W., 1977. Marine littoral diatoms - ecological considerations. In: Werner, D. (Ed.), The Biology of the Diatoms. Univ. of Cal. Press, Los Angeles, pp. 335-371.

McIntire, C.D., Overton, W.S., 1971. Distributional patterns in assemblages of attached diatoms from Yaquina Estuary. Oregon. Ecol. 52, 758-777.

Medlin, L.K., 1981. The effect of grazers on epiphytic diatom communities. In: Proceedings of the 6th International Symposium on Living and Fossil Diatoms, Budapest, Hungary. pp. 399-412.

Medlin, L.K., 1983. Community Analysis of Epiphytic Diatoms from Selected Species of Macroalgae Collected along the Texas Coast of the Gulf of Mexico. Ph.D. Dissertation Texas A\&M University, 151.
Medlin, L.K., 1991. Evidence for parallel evolution of frustule shape in two lines of pennate diatoms from the epiphyton. Diatom Res. 6, 109-124.

Medlin, L.K., Cembella, A., 2012. Biodiversity of harmful marine algae. In: second ed., In: Levin, S.A. (Ed.), Encyclopedia of Biodiversity, vol. 1, Academic Press, Waltham, MA, pp. $470-484$.

Medlin, L.K., Fryxell, G.A., Cox, E.R., 1985. Successional sequences of microbial colonization on three species of Rhodophycean macroalgae. Ann. Bot. 56, 399-413.

Millie, D.F., Lowe, R.L., 1983. Studies on Lake Erie's littoral algae; Host specificity and temporal periodicity epiphytic diatoms. Hydrobiol. (Sofia) 99, 7-18.

Moncreiff, C.A., Sullivan, M.J., 2001. Trophic importance of epiphytic algae in subtropical seagrass beds: evidence from multiple stable isotope analyses. Mar. Ecol. Prog. Ser. 215, 93-106.

Mutinová, P., 2015. Substrate Specificity of Epiphytic Communities of Diatoms (Bacillariophyceae) and Desmids (Desmidiales). Masters thesis Charles University of Prague, 72

Nicotri, M.E., 1977. Grazing effect of four marine intertidal herbivore on the microflora. Ecol. 58, 1020-1032.

Oksanen, J., Blanchet, F.G., Friendly, M., Kindt, R., Legendre, P., McGlinn, D., Minchin, P.R., O'Hara, R.B., Simpson, G.L., Solymos, P., Stevens, M.H.M., Szoecs, E., Wagner, H., 2017. Vegan: Community Ecology Package. R Package Version 2.4-3. https:// CRAN.R-project.org/package $=$ vegan

Overbeek, J.V., 1940. Auxin in marine algae. Plant Physiol. 15, 291-299.

Penhale, P., Smith Jr., W.O., 1977. Excretion of dissolved organic carbon by eelgrass (Zostera marina) and its epiphytes. Limnol. Oceangr. 22, 400-407.

Pielou, J., 1975. Ecological Diversity. Wiley Interscience, New York.

Pramitha, V.S., Lipton, A.P., 2013. Antibiotic potentials of red macroalgae hypnea musciformis (wulfen) lamouroux and Hypnea valentiae (turner) montagne. Sea Res. Util. 35, 95-107.

Prowse, G.A., 1959. Relationship between Epiphytic Algal Species and Their Macrophytic Host Nature, vol. 183, 1204-1205.

R Core Team, 2017. R: a Language and Environment for Statistical Computing. R Foundation for Statistical Computing, Vienna, Austria https://www.R-project.org/.

Ramm, G., 1977. Structure of epiphytic diatom populations of the phytal of the kiel bight (west baltic). Nova hedw. Beih 54, 379-387.

Rautianinen, H., Ravanko, O., 1974. The epiphytic diatom flora of the benthc macrophytic communities on rocky shores in the SW archipelago of Finland, Seili Island. Nova Hedwigia $23,827-842$.

Ricard, M., 1974. Etude taxonomique des diatomées marines du lagon de Vairao (Tahiti) 1. Le genre Mastogloia. Revue Algologique, nouvelle série 11, 161-177.

Rojas, L.A., Hassan, G.S., 2018. Distribution of epiphytic diatoms on five macrophytes from a Pampean shallow lake: host-specificity and implications for paleoenvironmental reconstructions. Diatom Res. 32, 263-275. https://doi.org/10.1080/0269249X. 2017.1378128

Ronnberg, O., Lax, P.E., 1980. Influence of wave action on morphology and epiphytic diatoms of Cladophora glomerata (L.) Kütz. Opelia (Suppl. 1), 209-218.

Rosen, B.H., Kingston, J.C., Lowe, R.L., 1981. Observations of differential epiphytism on Cladophora glomerata and Bangia atropurpurea from grand traverse bay, lake Michigan. Micro 12, 219-220.

Round, F.E., 1971. Benthic marine diatoms. Oceanogr. Mar. Biol. Annu. Rev. 9, 83-139.

Round, F.E., 1980. The benthic algae. Monogr. Biol. 32, 323-329.

Round, F.E., Crawford, R.M., Mann, D.G., 1990. The Diatoms. Biology and Morphology of the Genera. Cambridge University Press, New York, Port Chester, Melbourne, Sydney, 747.

Sand-Jensen, K., 1977. Effect of epiphytes on eelgrass photosynthesis. Aquat. Bot. 3, 55-63.

Sanmukh, S., Bruno, B., Ramakrishnan, U., Khairnar, K., Swaminathan, S., Paunikar, W. 2014. Bioactive compounds derived from microalgae showing antimicrobial activities. J. Aquacult. Res. Dev. 5, 224. https://doi.org/10.4172/2155-9546.1000224.

Shew, D.M., Baumann, R.H., Fritts, T.H., Dunn, L.S., 1981. Texas Barrier Islands Region Ecological Characterization: Environmental Synthesis Papers. US Fish Wildlife Ser Biological Services Program, Washington D.C, 413, FWS/OBS/81/32.

Sieburth, J.M., 1968. The influence of algal antibiosis on the ecology of marine microorganisms. In: Droop, M.R., EJF Wood (Eds.), Advances in Microbiology of the Sea. Academic Press, New York, pp. 63-94.

Sieburth, J.M., 1975. Microbial seascapes: a pictorial essay on marine microorganisms and their environments. University park press, baltimore. Plateau 3-9, 6-7.

Sieburth, J.M., Thomas, C.D., 1973. Fouling on eelgrass (Zostera marina L.). J. Phycol. 9, 46-50.

Sieburth, J.M., Tootle, J.L., 1981. Seasonality of microbial fowling on Ascophyllum nodosum (L.) lejol., Fucus vesiculosus L., Polysiphonia lanosa (L.) tandy and Chondrus crispus stackh. J. Phycol. 17, 57-64.

Sieburth, J.M., Brooks, R.A., Gessner, R.V., Thomas, C.D., Tootle, J.L., 1974. Microbial colonization of marine plant surfaces as observed by scanning electron microscopy. In: Effect of the Ocean Environment on Microbial Activities. University Park Press, Baltimore Maryland, pp. 418-432.

Simonsen, R., 1962. Untersuchungen zur Systematik und Ökologie der Bodendiatomeen der westlichen Ostsee. Akademie-Verlag, Berlin, 144

Siqueiros Beltrones, D.A., Martínez, Y.J., 2017. Prospective floristics of epiphytic diatoms on Rhodophyta from the southern Gulf of Mexico. CICIMAR Oceánides 32, 35-49.

Siver, P.A., 1978. Development of diatom communities of Potomogeton robbinsii Oakes. Rhodora 8, 417-430.

Siver, P.A., 1980. Microattachment patterns of diatoms on leaves of Potomogeton robbinsii Oakes. Trans. Am. Microsc. Soc. 99, 217-220.

Snoeijs, P., 1994. Distribution of epiphytic diatom species composition, diversity and biomass on different macroalgal hosts along seasonal and salinity gradients in the Baltic Sea. Diatom Res. 9, 189-211.

Snoeijs, P., 1995. Effects of salinity on epiphytic diatom communities on Pilayella littoralis (Phaeophyceae) in the Baltic Sea. Ecos 2, 382-394. 
Snoeijs, P., 1999. Diatoms and environmental change in brackish waters. In: Stoermer, E.F., Smol, J.P. (Eds.), The Diatoms: Applications for the Environmental and Sciences. Cambridge University Press, New York, pp. 298-333.

Stander, J.M., 1970. Diversity and Similarity of Benthic Fauna off Oregon. M.S. Thesis Orcgon State University, Corvallis, 72.

Steinberg, P.D., de Nys, R., 2002. Chemical mediation of colonization of seaweed surfaces J. Phycol. 38, 621-629.

Stevensen, R.J., 1981. Microphytobenthos Accumulation and Current. Ph.D. Dissertation University of Michigan, Ann Arbor.

Stevensen, R.J., Stoermer, E.F., 1982. Seasonal abundance patterns of diatoms on Cladophora in lake huron. J. Great Lake. Res. 8, 169-183.

Stowe, W.C., 1982. Diatoms epiphytic on the emergent grass Spartina alterniflora in a Louisiana salt marsh. Trans. Am. Microsc. Soc. 101, 162-173.

Sullivan, M.J., 1977. Structural characteristics of a diatom community epiphytic on Ruppia marittima. Hydrobiol. (Sofia) 53, 81-86.

Sullivan, M.J., 1980. Epiphytic diatoms of three seagrasses in Mississippi Sound. Bull. Mar. Sci. 29, 459-464.

Taasen, J.P., 1974. Remarks on the epiphytic diatom flora of Dumontia incrassata (Rhodophyceae). Sarsia 55, 129-132.

Taasen, J.P., 1975. Navicula fucicola sp. nov., a diatom living in the apical slit of Fucus vesiculosus. L. (Phaeophyceae). Sarsia 59, 1-6.
Tanaka, N., 1986. Adhesive strength of epiphytic diatoms on various seaweeds. Nippon Suisan Gakk 52, 817-821.

Tiffany, M.A., 2011. Epizoic and epiphytic diatoms. In: Seckbach, J., Kociolek, J.P. (Eds.), The Diatom World. Springer, pp. 195-211.

Totti, C., Poulin, M., Romagnoli, T., Perrone, C., Pennesi, C., de Stefano, M., 2009. Epiphytic diatom communities on intertidal seaweeds from Iceland. Polar Biol. https:// doi.org/10.1007/s00300-009-0668-4.

Underwood, G.J.C., Kromkamp, J., 1999. Primary production by phytoplankton and microphytobenthos in estuaries. Adv. Ecol. Res. 29, 93-153.

Underwood, G.J.C., Thomas, J.D., 1990. Grazing interactions between pulmonate snails and epiphytic algae and bacteria. Freshw. Biol. 23, 505-522.

Van de Ende, G., Haage, P., 1963. Beobachtungun über den Epiphytenbewuchs von Zostera marina L. an der bretonishen Küste. Bot. Mar. 5, 105-110.

Van den Ben, D., 1969. Les épiphytes des feuilles de Posidonia oceanica sur côtés français de la Méditerranée. Proc. Int. Seaweed Symp. 6, 79-84.

Whiting, M.C., 1983. Distributional Patterns and Taxonomic Structure of Diatom Assemblages in Netarts Bay, Oregon. Ph.D. Dissertation Oregon State University, Corvallis, 138.

Yüce, A.M., Gönülol, A., 2016. Evaluation of the relationship between epiphytic diatoms and environmental parameters with the canonical correspondence analysis (CCA). Pakistan J. Bot. 48, 1723-1730. 